TR 253

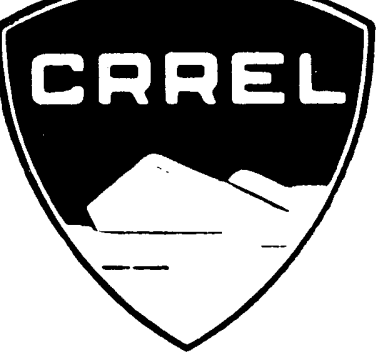

Technical Report 253

TRIAXIAL CONSTANT STRAIN RATE TESTS AND TRIAXIAL CREEP TESTS ON FROZEN OTTAWA SAND

Francis H. Sayles

August 1974

DIRECTORATE OF MILITARY CONSTRUCTION OFFICE, CHIEF OF ENGINEERS

BY CORPS OF ENGINEERS, USS. ARMY COLD REGIONS RESEARCH AND ENGINEERING LABORATORY HANOVER, NEW HAMPSHIRE

APPROVED FOR PUBLIC RELEASE; DISTRIBUTION UNLIMITED. 
The findings in this report are not to be construed as an official Department of the Army position unless so designated by other authorized documents. 


\title{
TRIAXIAL CONSTANT STRAIN RATE TESTS AND TRIAXIAL CREEP TESTS ON FROZEN OTTAWA SAND
}

\author{
Francis H. Sayles
}

August 1974

\author{
PREPARED FOR \\ DIRECTORATE OF MILITARY CONSTRUCTION \\ OFFICE, CHIEF OF ENGINEERS \\ CORPS OF ENGINEERS, U.S. ARMY
}

COLD REGIONS RESEARCH AND ENGINEERING LABORATORY

HANOVER, NEW HAMPSHIRE 


\section{PREFACE}

This report was prepared by Francis H. Sayles, Research Civil Engineer, Northern Engineering Research Branch, Experimental Engineering Division, U.S. Army Cold Regions Research and Engineering Laboratory. The study was conducted for the Directorate of Military Construction, Office of the Chief of Engineers. The program was under the technical direction of the Engineering Division of this directorate; Civil Engineering Branch.

The author is appreciative of assistance given by personnel in the testing laboratory. Specifically, thanks go to R. Bonnett, J. Ingersoll, A. Greatorex, D. May, J. Schweizer and J. Watts. The constructive comments on the final manuscript by E. Chamberlain and W. Quinn and Dr. G. Swinzow are gratefully acknowledged. 


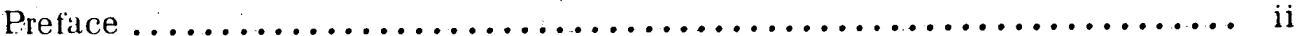

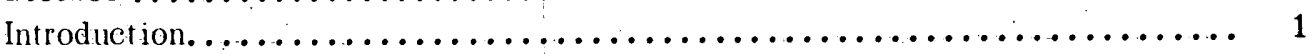

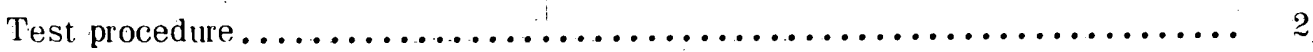

Triaxial tests at constant strain rate.......................... 2

Creep under hydrostatic stress confining pressure conditions $\ldots \ldots \ldots \ldots \ldots \ldots, 7$

Triaxial creep strength................................... 12

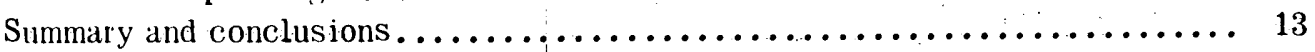

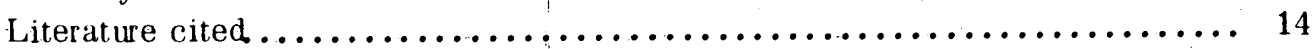

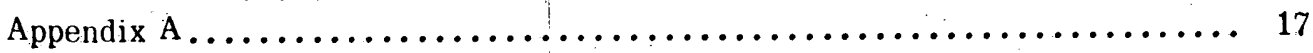

Appendix B: Triaxial test stress-strain curves $\ldots \ldots \ldots \ldots \ldots \ldots \ldots \ldots \ldots \ldots .21$

Abstract. ........................................... 29

Figure

1. Axial stress-strain curves for Ottawa sand and ice at different confin-

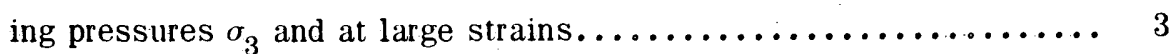

?. Mohr envelopes for Cttawa sand and ice .................... 3

3. Axial stress-strain curves for Ottawa sand at small strains ......... 4

4. Strength vs confining pressure $\sigma_{3}$ for Ottawa sand $\ldots \ldots \ldots \ldots \ldots \ldots \ldots$

5. Mohr envelopes for Ottawa sand at different strain rates $\ldots \ldots \ldots \ldots \ldots .6$

6. Strength vs applied strain rate for Ottawa sand $\ldots \ldots \ldots \ldots \ldots \ldots \ldots \ldots 7$

7. Summary creep curves for Ottawa sand at different confining pressures and axial stresses................................. 8

8. Creep curves for Ottawa sand at constant axial stress and different confining pressures................................ 10

9. Time vs creep strain rate for Ottawa sand .................. 10

10. Measured compared with predicted creep strain for Ottawa sand....... 11

11. Creep strength vs time to failure for Ottawa sand ............... 12

12. Mohr envelopes for creep strength of Ottawa sand $\ldots \ldots \ldots \ldots \ldots \ldots, 12$ 


\section{TRIAXIAL CONSTANT STRAIN RATE TESTS AND TRIAXIAL CREEP TESTS ON FROZEN OTTAWA SAND}

by

Francis H. Sayles

\section{INTRODUCTION}

Triaxial compression tests using a constant rate of applied strain and triaxial creep tests using a constant load were conducted on saturated frozen Ottawa sand (20-30 mesh) and ice to gain a better understanding of the factors that influence the strength and deformation characteristics of frozen soils. Several published results of conventional unconfined compression tests, direct shear tests and unconfined compression creep tests* show that the strength and deformation of a given frozen soil are strongly dependent upon temperature and duration of applied stress. Although Vyalov ${ }^{10}$ discussed triaxial testing of frozen soil and suggested a generalized creep theory taking hydrostatic pressure into account, and Andersland and AlNouri ${ }^{2}$. presented data from triaxial tests on Ottawa sand using confining pressures up to about $0.62 \times 10^{6} \mathrm{~N} / \mathrm{m}^{2}(90 \mathrm{psi})$, the influence of conf ining pressure and rate of loading on strength and deformation have not been fully assessed.

Strength and deformation of frozen soils, as with unfrozen cohesive soils, depend upon both the cohesion and the internal friction of the component materials. According to Vyalov and Tsytovich, ${ }^{11}$ the cohesion component in frozen soils can be attributed to: 1) molecular forces of attraction between particles, 2) physical or chemical cementing of particles together, and 3) cementing of particles by ice formation in the soil voids. The cementation by ice is the result of the bonds between the ice crystals and the soil particles even though the soil particles are surrounded by a film of unfrozen water. This cementation implies that the unfrozen water under the influence of molecular forces of the soil particles is capable of transmitting normal and even some shear forces between the solid ice and the solid soil grains. The cohesion depends upon the amount, strength, and area of ice in contact with the soil particles, each of which is temperature dependent. The internal friction depends upon the ice content; the soil grain arrangement, size, distribution and shape; and the number of grain-to-grain contacts. ${ }^{811}$ Except for the ice content, each of these factors is independent of temperature.

The purpose of this investigation was to study the effects of hydrostatic confining pressure and the rate of applied load on the strength and deformation characteristics of frozen sands and to assess the relative influence of the cohesion of the ice matrix versus the friction between the particles of sand.

Rels, $1,2,4,5,7,8,9$ and 12. 


\section{TEST PROCEDURE}

The testing was conducted on cylindrical specimens about $70 \mathrm{~mm}(2.75 \mathrm{in}$.$) in diameter and$ about $152.5 \mathrm{~mm}$ (6.0 in.) long. These dimensions were chosen to ensure a large ratio between specimen diameter and soil particle size and to use existing available testing apparatus. Each sand specimen was packed in a freezing mold, saturated with distilled, de-aired water under about $700 \mathrm{~mm}$ of mercury vacuum, then frozen from the top down in an open system where free water had access to the bottom of the specimen. The rate of progress of the $0^{\circ} \mathrm{C}\left(32^{\circ} \mathrm{F}\right)$ isotherm was determined by means of thermocouples spaced $25.4 \mathrm{~mm}(1 \mathrm{in}$.) apart along the vertical axis of a control specimen. Soil samples were frozen within a period of 4 days and the average rate of front penetration was about $38 \mathrm{~mm}\left(1 \frac{1 / 2}{2}\right.$ in.) per day. No expansion of the specimens was observed during the freezing process. The increase in volume because of the change in phase of the water to ice was absorbed in the free water supply connected to the bottom of the specimen. The ice specimens used in this study were prepared in a manner similar to that of the sand. All specimens were trimmed to ensure that the ends were perpendicular to the axis and were enclosed in two and sometimes three rubber membranes to prevent the intrusion of the confining fluid (ethylene glycol and water). The Ottawa sand specimens were saturated and had an average dry unit weight of about $1670 \mathrm{~kg} / \mathrm{m}^{3}\left(104 \mathrm{lb} / \mathrm{ft}^{3}\right)$, a void ratio of about 0.59 , and a porosity of $37 \%$; and the specific gravity of the soil particles was 2.65. The average dry unit weight of the ice specimens was about 913 $\mathrm{kg} / \mathrm{m}^{3}\left(56.9 \mathrm{lb} / \mathrm{ft}^{3}\right)$. Values for each specimen are given in Tables AI and AII in the Appendix.

Nominal hydrostatic confining pressures $\sigma_{3}$ of $0.34 \times 10^{6} \mathrm{~N} / \mathrm{m}^{2}(50 \mathrm{psi})$ to $8.2 \times 10^{6} \mathrm{~N} / \mathrm{m}^{2}$ $(1200 \mathrm{psi})$ were used; superimposed axial (deviator) stresses $\left(\sigma_{1}-\sigma_{3}\right) *$ in the creep tests were $0.525 \times 10^{6} \mathrm{~N} / \mathrm{m}^{2}(75 \mathrm{psi})$ to $6.89 \times 10^{6} \mathrm{~N} / \mathrm{m}^{2}(1000 \mathrm{psi})$; the test temperature was $-3.85^{\circ} \mathrm{C}\left(25^{\circ} \mathrm{F}\right)$. In the compression tests the diameter of the specimen increased with axial deformation. The resulting axial stresses were computed on the assumption that the volume of the specimen remained constant and the specimen remained a cylinder throughout each test. These assumptions were consistent with visual observations.

\section{TRIAXIAL TESTS AT CONSTANT STRAIN RATE}

Laboratory data from the constant rate of strain tests show that the shape of the stress-strain curve and the maximum or peak stresses are governed by the rate of applied strain and the magnitude of the hydrostatic confining pressure. Stress-strain curves for a rate of applied strain of about $0.03 / \mathrm{min}$ are shown in Figure 1 . Where strains exceed about 0.1 , two peak stresses occur when the confining pressure $\sigma_{3}$ is above about $2.7 \times 10^{6} \mathrm{~N} / \mathrm{m}^{2}(400 \mathrm{psi})$. The first peak occurs at strains less than 0.01 and the second at a strain of abcut 0.1 . The strain at which the first stress peak occurs is close to the strain at failure for columnar-grained ice specimens (i.e. where the ice crystals are columns with axes parallel to those of the cylinder specimen) also shown in Figure 1. This observation suggests that the first peak is essentially the consequence of the strength of the ice matrix and the second is the development of friction between grains of sand and/or ice crystals as the strain progresses. The frictional resistance increases until the maximum dilatancy of the sand grains is reached and the second peak in the stress-strain curve is attained.

Since the strength due to internal friction of the sand increases with confining pressure and for practical purposes the cohesion of an ice crystal does not, the second peak of the stress-strain

* $\left(\sigma_{1}-\sigma_{3}\right)$ is the axial deviator stress where $\sigma_{1}$ is the major principal stress and $\sigma_{3}$ is the hydrostatic confining pressure. 


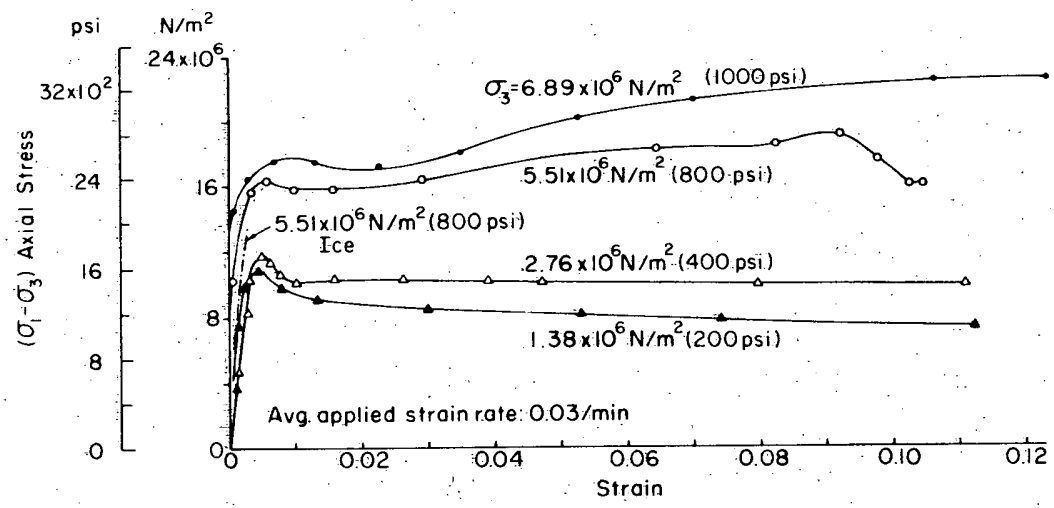

Figure 1. Axial stress-strain curves for Ottawa sand and ice at different confining pressures $\sigma_{3}$ and at large strains.

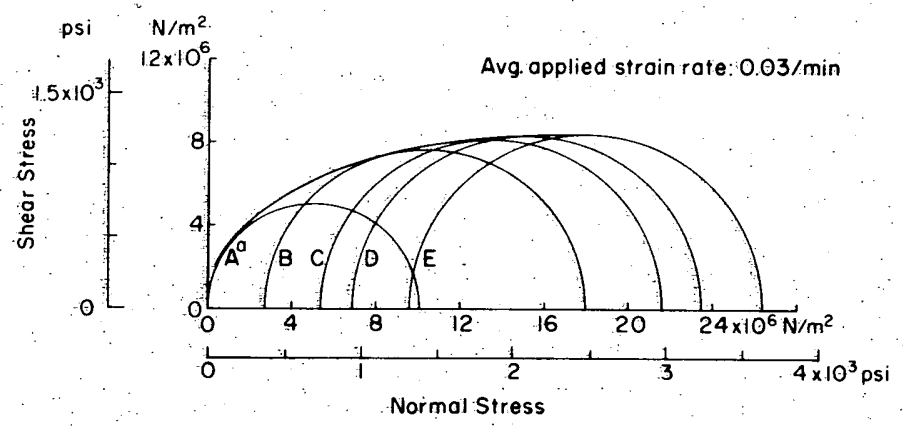

a. Ottawa Sand First Resistance Peak

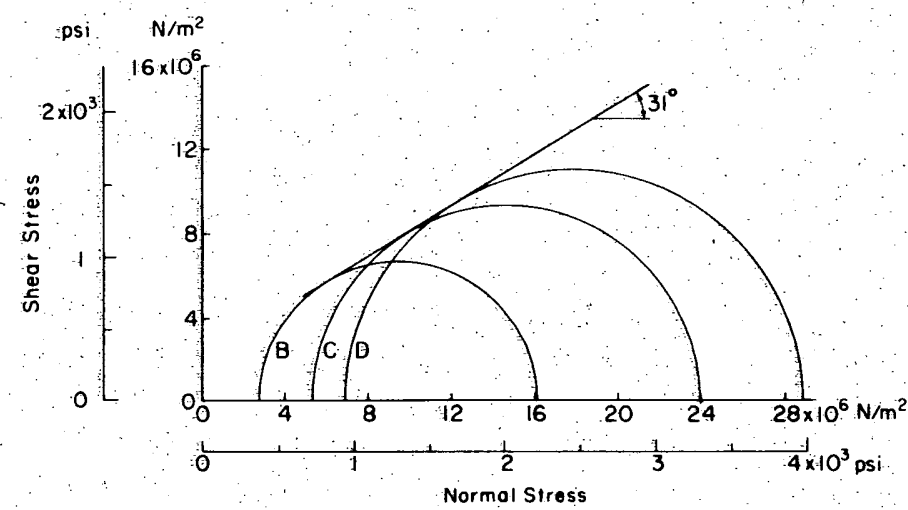

b. Ottowa Sond Second Resistance Peak

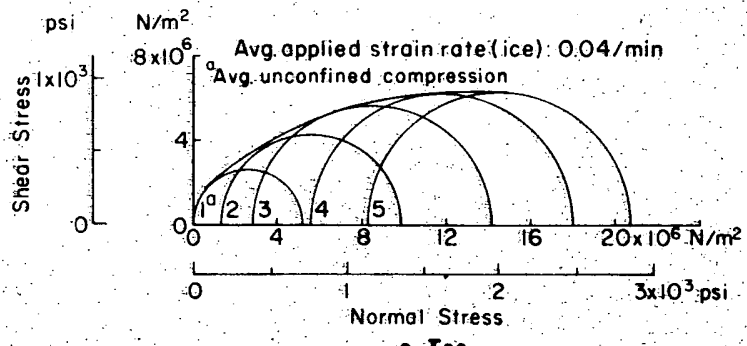

c. Ice

Figure 2. Mohr envelopes for Ottawa sand and ice. $A-E$ and 1-5 on curves indicate different specimens of sand and ice. 


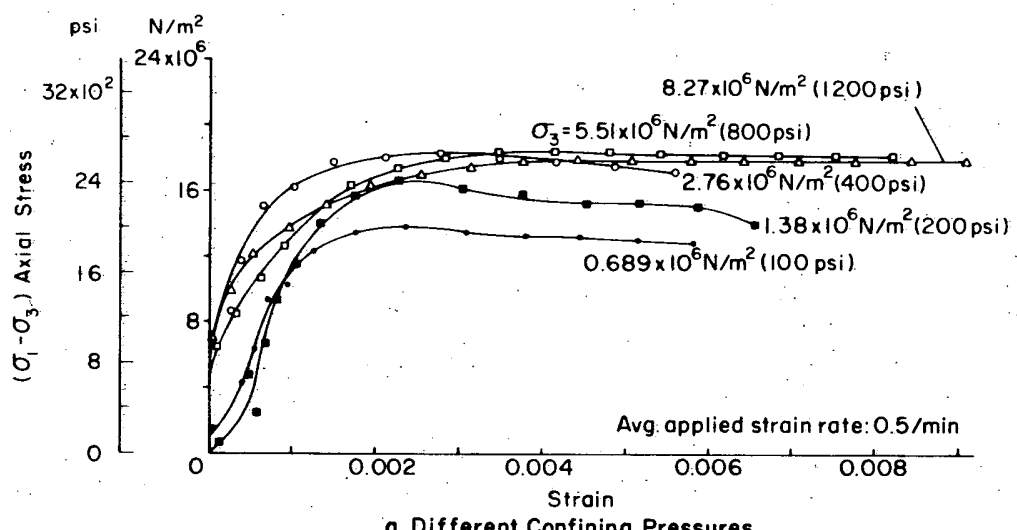

a. Different Confining Pressures

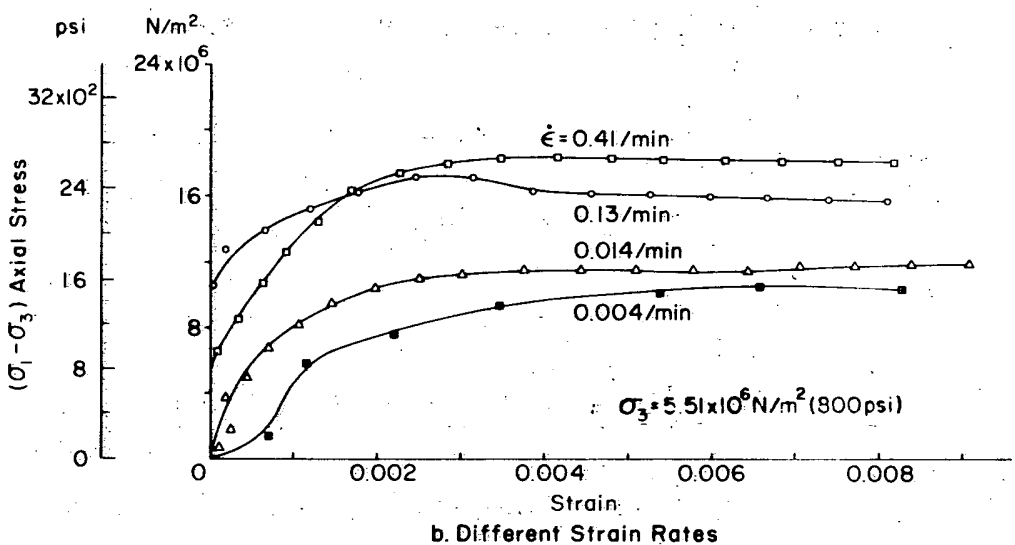

Figure 3. Axial stress-strain curves for Ottawa sand at small strains.

curve may be smaller than the first peak for low confining pressures and greater than the first peak for high confining pressures. In fact, it was observed, and is shown in Figure 1 , that for confining pressure below $2.76 \times 10^{6} \mathrm{~N} / \mathrm{m}^{2}(400 \mathrm{psi})$ the frictional resistance might be considered as an apparent constant residual strength for each confining pressure.

The concept that each peak strength represents the domination of either the cohesive or frictional strength separately is reinforced by the two Mohr strength envelopes shown in Figure 2. The envelope in Figure $2 \mathrm{~b}$ is nearly a straight line with an angle of internal friction of about $31^{\circ}$, a value similar to that of unfrozen Ottawa sand. The envelope in Figure $2 a$ is curved for the lower values of confining pressure, indicating that there is some internal friction involved at these lower levels of confining pressures. However, this envelope approaches nearly a constant value at the higher confining pressures, suggesting that cohesion provides nearly all resistance at these conf ining pressures and small strains. The influence of confining pressure on the stress-strain curve for the first stress peak for the constant rate of applied strain of $0.5 / \mathrm{min}$ is shown in Figure 3a. The first peak stresses increase with confining pressure up to pressures of about $2.7 \times 10^{6} \mathrm{~N} / \mathrm{m}^{2}(400$ psi), and above this value the confining pressure appears to have little influence on the strength.

The Mohr envelope for polycrystalline columnar-grained ice (Fig. 2c) also shows that for confining pressures below $2.7 \times 10^{6} \mathrm{~N} / \mathrm{m}^{2}$ (400 psi) the ice has a strength dependency on conf ining pressure and above $2.7 \times 10^{6} \mathrm{~N} / \mathrm{m}^{2}(400 \mathrm{psi})$ the strength of the ice is nearly independent of confining pressure. The curve is consistent with the concept that the first peak stress on the stressstrain curve is a reflection of the influence of the ice matrix of the soil. 


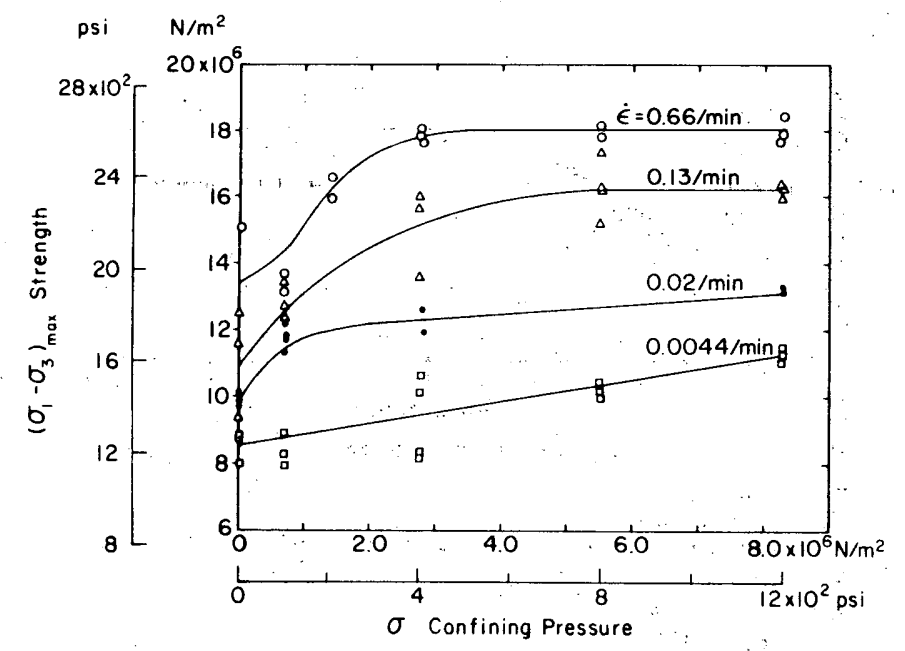

Figure 4. Strength vs confining pressure $\sigma_{3}$ for Ottawa sand.

The strength dependency of polycrystalline ice upon confining pressure below about $2.7 \times 10^{6}$ $\mathrm{N} / \mathrm{m}^{2}$ (400 psi) could be attributed to the friction between the individual ice crystals. As the confining pressure is increased above $2.7 \times 10^{6} \mathrm{~N} / \mathrm{m}^{2}(400 \mathrm{psi})$, the ice crystals are pressed together and tend to resist the applied stress as a combined single crystal. The nearly constant shearing strength of about $6.2 \times 10^{6} \mathrm{~N} / \mathrm{m}^{2}(900 \mathrm{psi})$ shown in Figure 2c is greater than the values reported ${ }^{3}$ for a single ice crystal tested along the glide direction. This result is expected because it would be improbable for the glide planes of the crystals in the polycrystalline ice to have the same orientation and hence the same resistance to shear as a single crystal. Also to be noted in Figures 2a and $2 \mathrm{c}$ is the difference in Mohr envelopes, indicating that in samples of frozen sand some shearing resistance at the first peak of the stress-strain curve is contributed by the arrangement of sand grains.

The shapes of the stress-strain curves for the first resistance peak shown in Figure $3 \mathrm{~b}$ suggest a plastic type of failure rather than a brittle failure ending in an abrupt fracture. These curves indicate that as the rate of applied strain increases the maximum peak resistance increases. It is questionable whether the resistance can increase indefinitely with the increase in strain rate before some other phenomenon such as brittle fracturing of the ice matrix limits the first peak resistance of the frozen sand.

As shown in Figure 4, the combined effect of increasing applied strain rate $\dot{\epsilon}$ and confining pressure on the first or cohesion peak strength shows that the peak strengths for rates of strain above about $0.02 / \mathrm{min}$ increase with confining pressure up to about $2.7 \times 10^{6} \mathrm{~N} / \mathrm{m}^{2}(400 \mathrm{psi})$, then appear to be independent of confining pressure. At the lower rates of strain (below $0.02 / \mathrm{min}$ ) the strength increases with increase in confining pressure; this suggests that friction between the sand grains is being activated, possibly because the ice matrix is allowed time to creep from between the sand grains where the stress concentration is high, thus bringing more sand grains into closer contact and hence creating greater frictional resistance.

Mohr envelopes for the first resistance peak of frozen sand for different rates of applied axial strain are plotted in Figure 5. Figure 5 also shows the combined effect of rate of strain and confining pressure. Again, above a confining pressure of about $2.7 \times 10^{6} \mathrm{~N} / \mathrm{m}^{2}(400 \mathrm{psi})$ the slope of the envelope is small. The slopes of the envelopes at the higher confining pressure are greater for the lower strain rates, possibly reflecting the friction between the ice crystals as well as the friction between the soil grains that have crept closer together. 


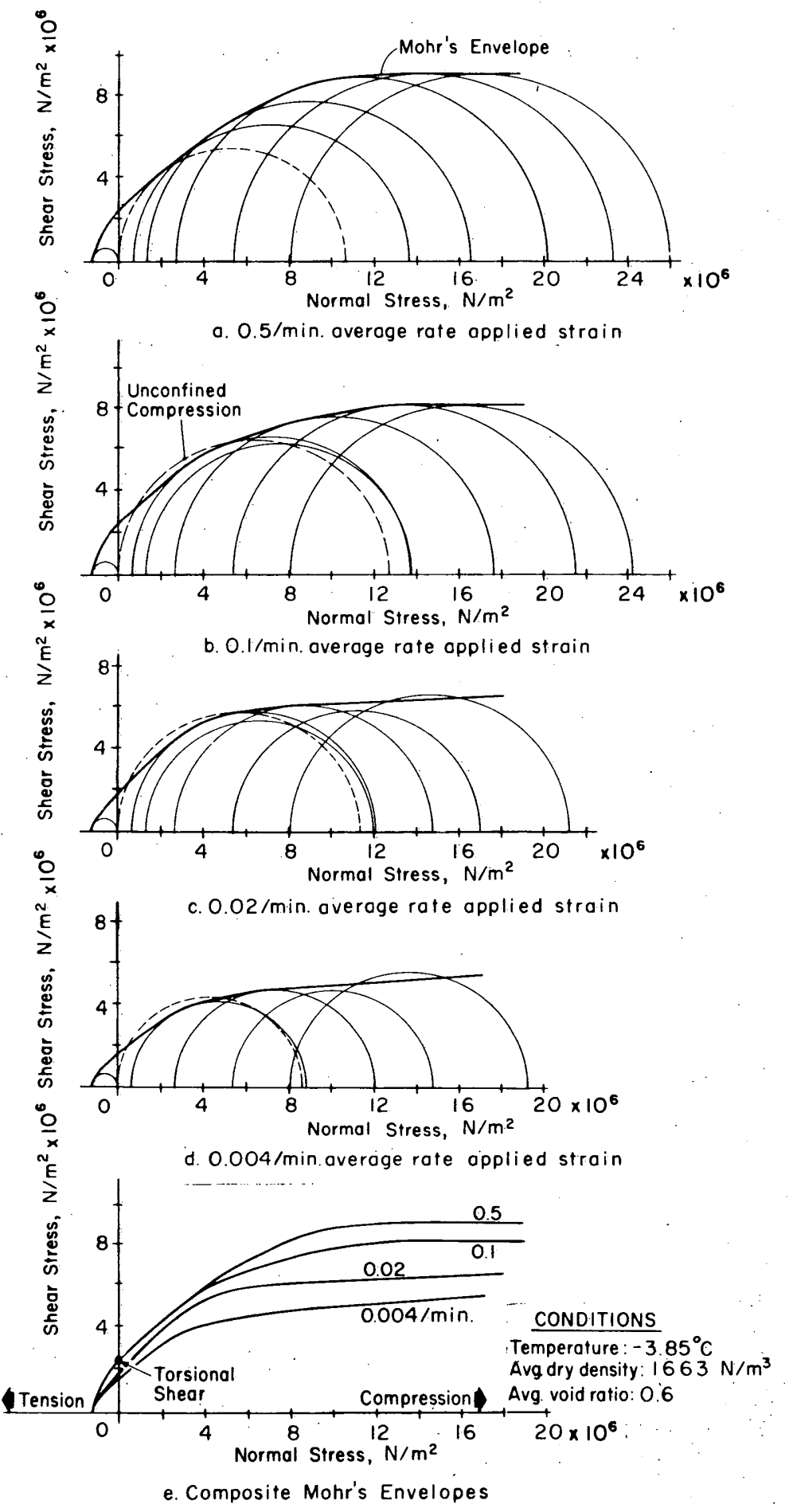

Figure 5. Mohr envelopes for Ottawa sand at different strain rates. 


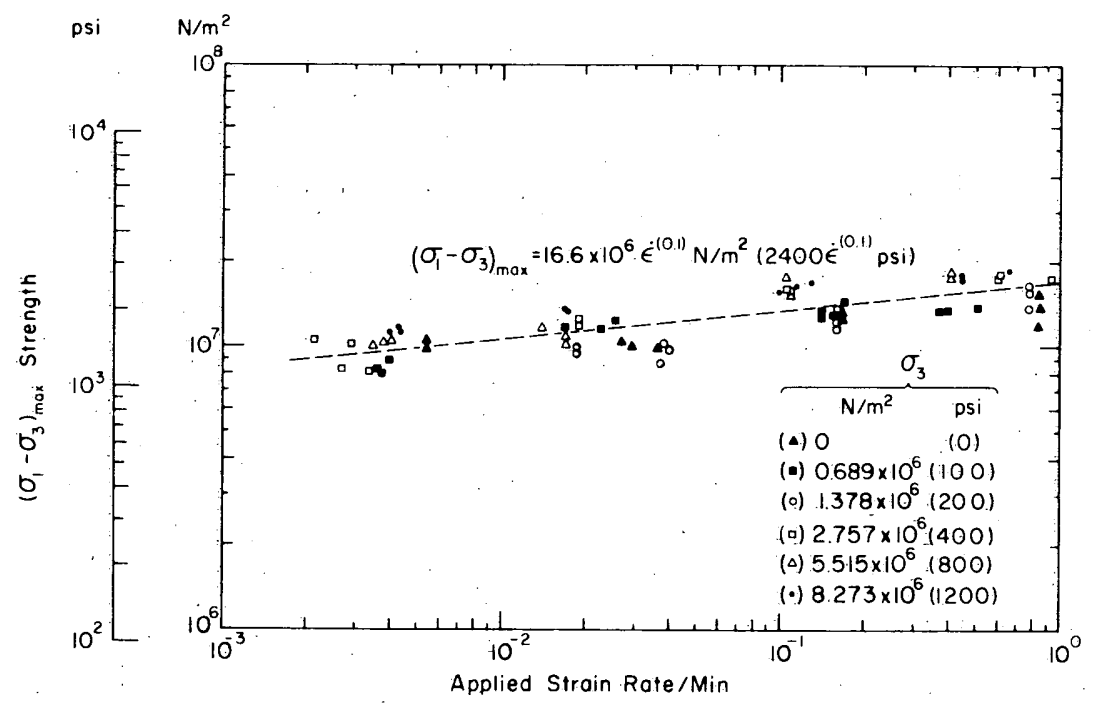

Figure 6. Strength vs applied strain rate for Ottawa sand.

There is evidence from unconfined compression tests that the strength of frozen Ottawa sand does not increase indefinitely as the rate of applied strain increases but is limited by a brittle type of failure at strain rates greater than $0.5 / \mathrm{min}$. Nevertheless, the data obtained for confined compression in this investigation can be represented by the straight line shown in Figure 6 and the expression

$$
\left(\sigma_{1}-\sigma_{3}\right)_{\mathbf{c}}=16.6 \times 10^{6}(\dot{\epsilon})^{0.1}
$$

where $\left(\sigma_{1}-\sigma_{3}\right)=$ first peak stress or strength in $\mathrm{N} / \mathrm{m}^{2}$

$\dot{\epsilon}=$ applied rate of strain per minute.

This expression was derived using all constant applied strain rate test data obtained in this investigation and unconfined compression data from reference 5. Figure 6 is presented merely to show that the general trend is for the strength to increase as the rate of applied strain increases within the limits of the strain rates shown.

\section{CREEP UNDER HYDROSTATIC STRESS CONFINING PRESSURE CONDITIONS}

The time versus creep strain curves for constant confining pressures shown in Figure 7 summarize data from creep tests conducted in this investigation. Where more than one specimen was tested, a single curve represents the average for the specimens. The vertical bars on the curves give the total range of strain values at the location of the bar. The adjusted true strains were computed after accounting for the deformation of the test machine and the instantaneous deformation of the specimen by subtracting the initial deformation reading - the reading taken 5 seconds after application of the load. Since constant load tests were performed instead of constant stress tests, the strains were adjusted to a constant stress basis by assuming that the volume of the specimen remained constant and the specimen remained a cylinder throughout each test.

Although considerable care was taken to repeat each of the tests by preparing each specimen using the same process in every detail, by testing each replication under as nearly identical 


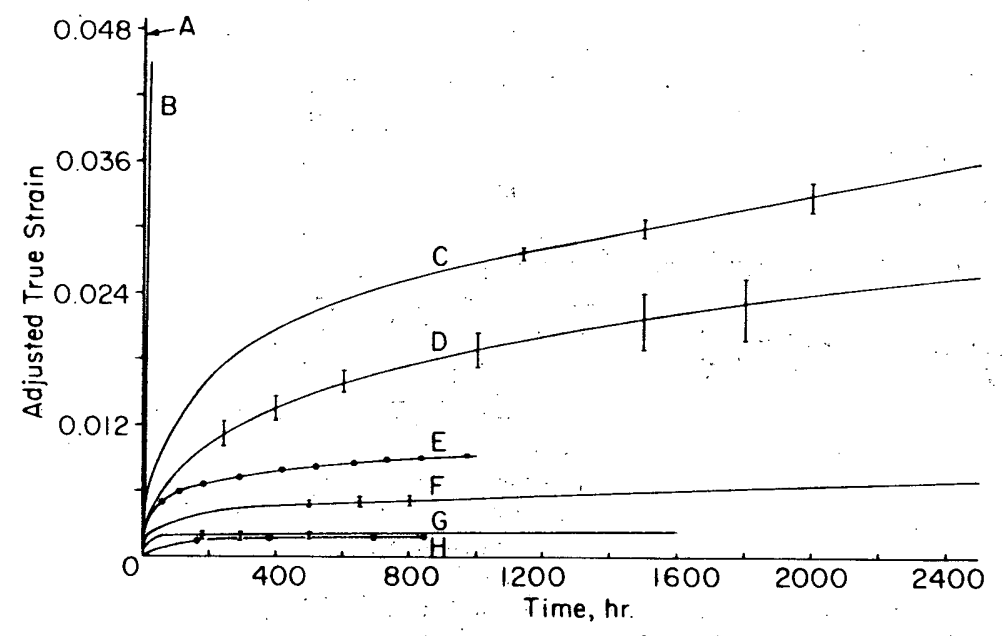

\begin{tabular}{|c|c|c|c|}
\hline \multirow{2}{*}{ Curve } & \multicolumn{2}{|c|}{$\bar{\sigma}_{1}-\bar{\sigma}_{3}$} & \multirow{2}{*}{$\begin{array}{c}\text { OWS } \\
\text { Specimen No's }\end{array}$} \\
\hline & $\mathrm{N} / \mathrm{m}^{2}$ & psi & \\
\hline A & $4.13 \times 10^{6}$ & 600 & 468,4 \\
\hline$B$ & & 400 & \\
\hline C & & 250 & \\
\hline D & & 200 & 35 \\
\hline$E$ & $0^{6}$ & 100 & 55 \\
\hline $\mathrm{F}$ & $0^{6}$ & 5 & 352 \\
\hline G & 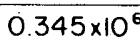 & 50 & 562 \\
\hline & $108 \times 10^{6}$ & 15.6 & 374 \\
\hline
\end{tabular}

a.) $\sigma_{3}=0.345 \times 10^{6} \mathrm{~N} / \mathrm{m}^{2}(500 \mathrm{psi})$

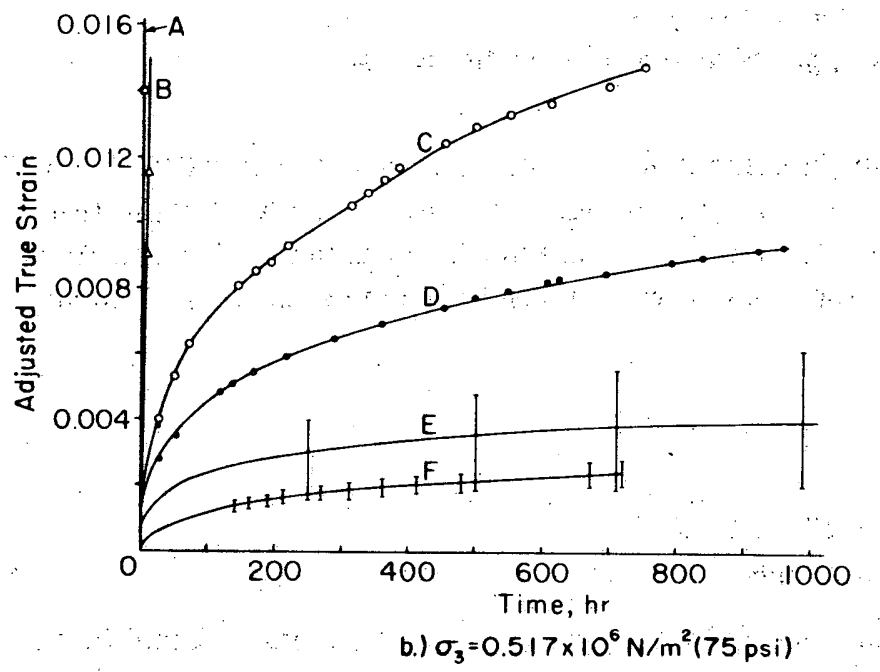

\begin{tabular}{|c|c|r|l|}
\hline \multirow{2}{*}{ Curve } & \multicolumn{2}{|c|}{$\sigma_{1}-\sigma_{3}$} & \multicolumn{1}{c|}{ Ows } \\
\cline { 2 - 4 } & $\mathrm{N} / \mathrm{m}^{2}$ & psi & Specimen No's \\
\hline A & $4.13 \times 10^{6}$ & 600 & $466,472,476$ \\
\hline$B$ & $2.76 \times 10^{6}$ & 400 & 482 \\
\hline$C$ & $1.38 \times 10^{6}$ & 200 & 463 \\
\hline$D$ & $1.03 \times 10^{6}$ & 150 & 391 \\
\hline$E$ & $0.517 \times 10^{6}$ & 75 & 392,461 \\
\hline$F$ & $0.256 \times 10^{6}$ & 37.2 & 424,429 \\
\hline
\end{tabular}

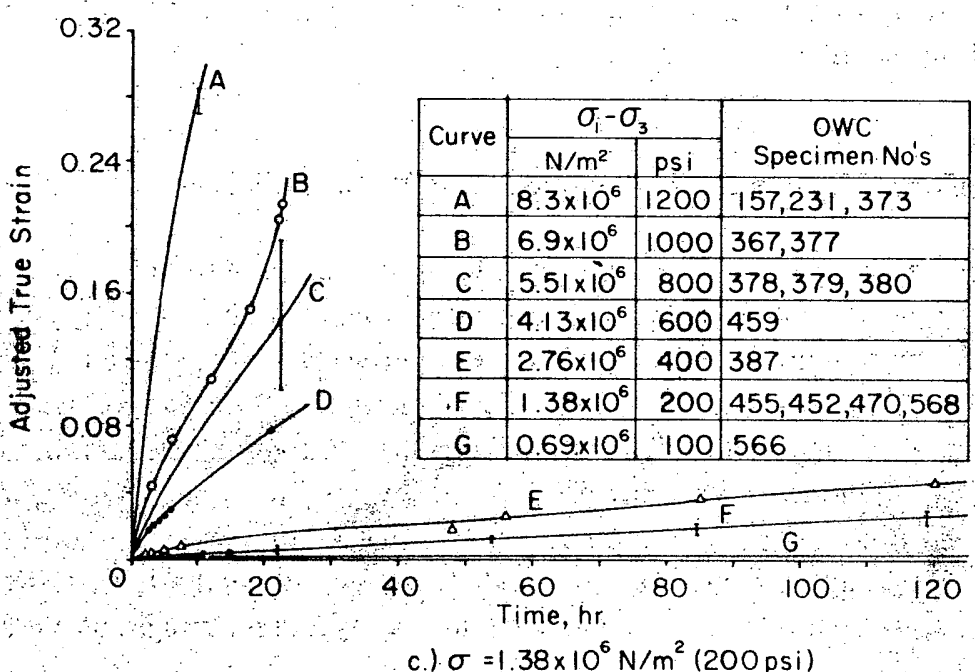

Figure 7. Summary creep curves for Ottawa sand at different confining pressures and axial stresses. 

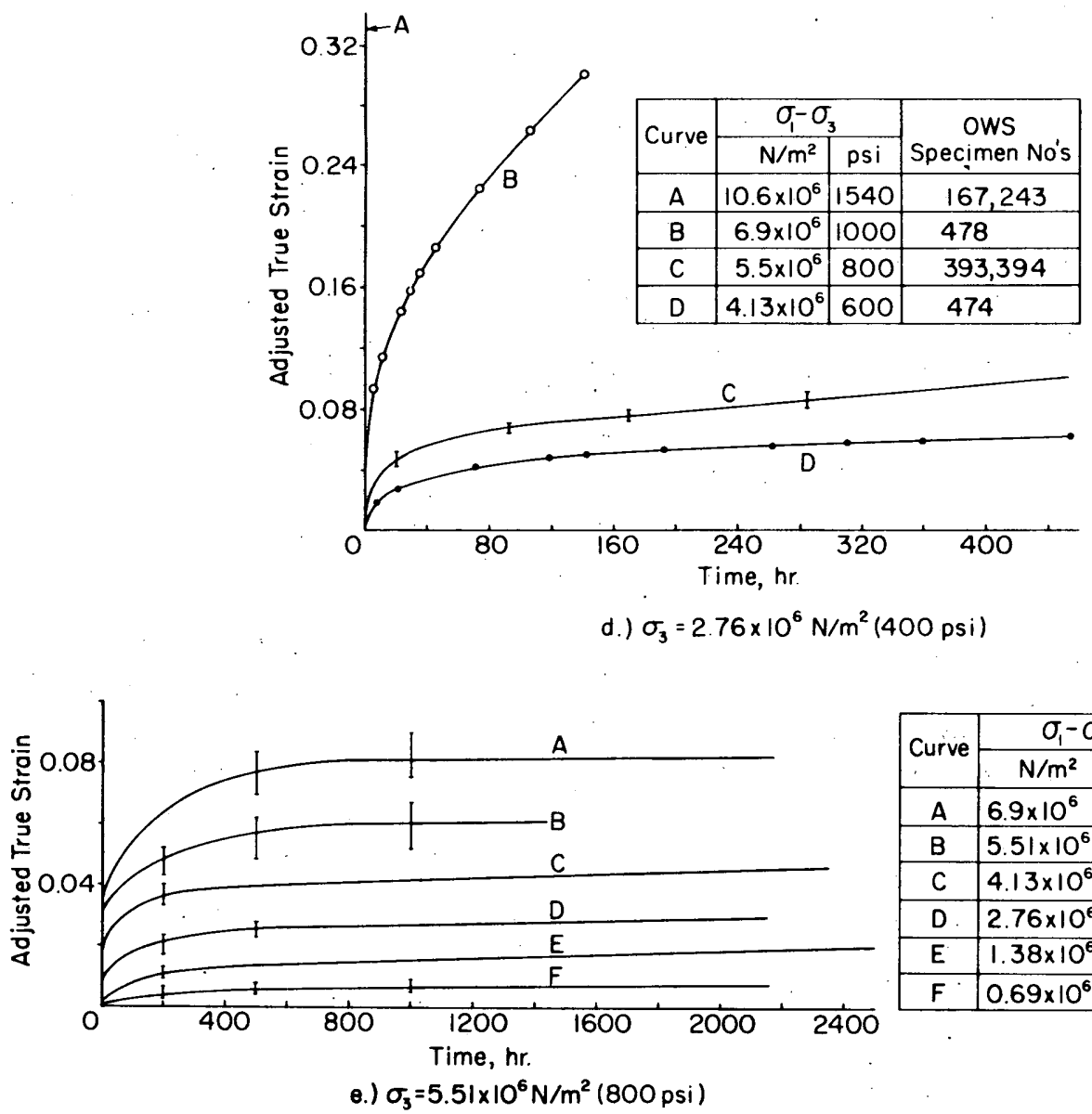

\begin{tabular}{|c|c|c|c|}
\hline \multirow{2}{*}{ Curve } & \multicolumn{2}{|c|}{$\sigma_{1}-\sigma_{3}$} & \multirow{2}{*}{$\begin{array}{c}\text { OWS } \\
\text { Specimen No's }\end{array}$} \\
\hline & $\mathrm{N} / \mathrm{m}^{2}$ & psi & \\
\hline$A$ & $6.9 \times 10^{6}$ & 1000 & 499,500 \\
\hline$B$ & $5.51 \times 10^{6}$ & 800 & $511,518,535$ \\
\hline $\mathrm{C}$ & $4.13 \times 10^{6}$ & 600 & 539,521 \\
\hline$D$ & $2.76 \times 10^{6}$ & 400 & $538,525,540$ \\
\hline$E$ & $1.38 \times 10^{6}$ & 200 & 505,515 \\
\hline $\mathrm{F}$ & $0.69 \times 10^{6}$ & 100 & $534,545,552$ \\
\hline
\end{tabular}

Figure 7 (cont'd). Summary creep curves for Ottawa sand at different confining - pressures and axial stresses.

conditions as possible, and by controlling the temperature within $0.1^{\circ} \mathrm{C}\left(0.18^{\circ} \mathrm{F}\right)$, there was considerable variation in the results, as shown by the size of the vertical bars on the summary creep curves. This variation is especially noticeable for the lower axial stress levels where the vertical bars overlap adjacent creep curves (Fig. $7 a$ and b).*

As expected, these creep curves show that for a given confining pressure the magnitude of the strain at any given time increases with stress level. The effect of increasing the confining pressure is to reduce the amount of creep strain for a given period of constant axial stress application. This effect is demonstrated in Figure 8 where the axial stress is held constant and the confining pressure is increased. In comparing creep curves from triaxial tests with those from unconf ined compression tests, ${ }^{8}$ it was noticed that the first stage or primary creep was prolonged in the triaxial tests and that strains greater than 0.2 were reached without secondary creep being attained.

An examination of the various curves of this investigation at the lower stress levels indicates that the rate of strain decreases continuously with time in a manner suggesting that an empirical power function relationship between the rate of creep strain and time may exist. The logarithmic plots of strain versus time data in Figure 9 can be represented by a straight line and the expression:

* Confining pressures were applied about 24 hours before the axial load was applied. 


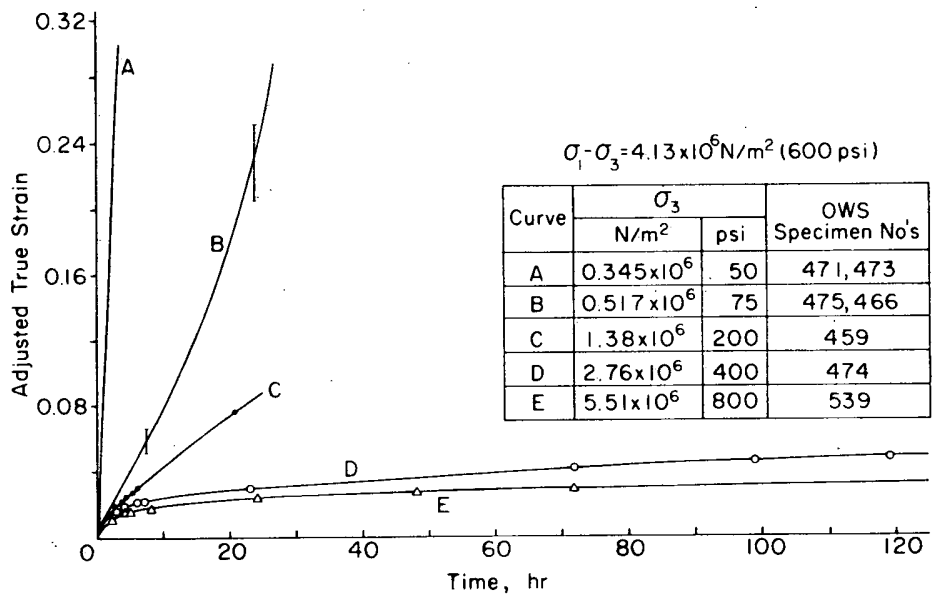

Figure 8. Creep curves for Ottawa sand at constant axial stress $\left(\sigma_{1}-\sigma_{3}\right)$ and different confining pressures $\left(\sigma_{3}\right)$.

\begin{tabular}{|c|c|c|c|}
\hline \multirow{2}{*}{ Line } & \multicolumn{2}{|c|}{$\sigma_{1}-\sigma_{3}$} & \multirow{2}{*}{$\begin{array}{c}\text { OWS } \\
\text { Specimen No }\end{array}$} \\
\hline & $\mathrm{N} / \mathrm{m}$ & psi & \\
\hline A & $1.0 \times 10^{6}$ & 145 & 391 \\
\hline B & $0.517 \times 10^{6}$ & 75 & 496 \\
\hline$c$ & $0.26 \times 10^{6}$ & 37.5 & 424 \\
\hline
\end{tabular}

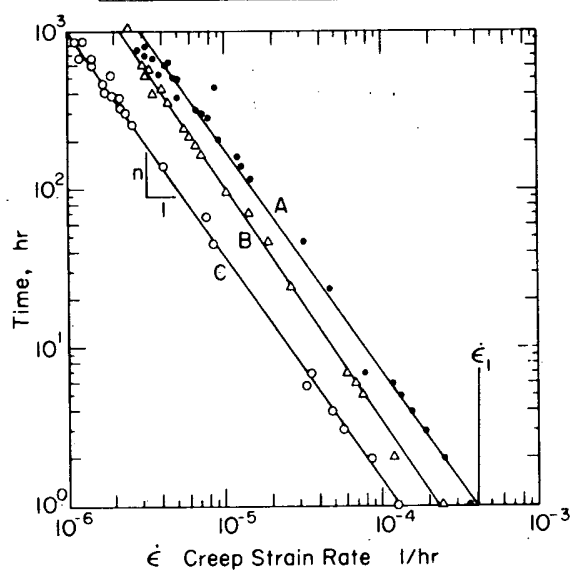

Figure 9. Time vs creep strain rate for Ottawa sand.

$$
\dot{\epsilon} / \dot{\epsilon}_{\mathrm{R}}=\left(t / t_{\mathrm{R}}\right)^{1 / n}
$$

or

$$
\dot{\epsilon}=\left[\dot{\epsilon}_{\mathrm{R}} /\left(t_{\mathrm{R}}\right)^{1 / n}\right](t)^{1 / n}
$$

where $\dot{\epsilon}=$ rate of strain at any time $t$ greater than zero

$t_{\mathrm{R}}=\mathrm{a}$ reference time greater than zero

$\dot{\epsilon}_{\mathrm{R}}=$ a corresponding strain rate

$n=$ the slope of the straight line on the plot.

Any convenient value for a reference time $t_{\mathrm{R}}$ greater than zero can be selected. However, by selecting a value from the early portion of the curve, future rates of strain can be predicted. Often $t_{\mathrm{R}}$ taken as 1 hour is convenient; then $\dot{\epsilon}_{\mathrm{R}}$ becomes $\dot{\epsilon}_{1}$ and

$$
\dot{\epsilon}=\dot{\epsilon}_{1} t^{1 / n} \text {. }
$$

To obtain an expression for strain at any time, eq 1 can be integrated.

$$
\begin{gathered}
\dot{\epsilon}=\left(d_{\epsilon} / d t\right)=\left[\dot{\epsilon}_{\mathrm{R}} /\left(t_{\mathrm{R}}\right)^{1 / n}\right](t)^{1 / n} \\
\int_{\epsilon_{\mathrm{r}}}^{\epsilon} d_{\epsilon}=\dot{\epsilon}_{\mathrm{R}} /\left(t_{\mathrm{R}}\right)^{1 / n} \int_{t_{\mathrm{r}}}^{t}(t)^{1 / n} d t \\
\epsilon-\epsilon_{\mathrm{r}}=\left[\dot{\epsilon}_{\mathrm{R}} /\left(t_{\mathrm{R}}\right)^{1 / n}\right][n /(n+1)]\left[t^{(n+1) / n}-t_{\mathrm{r}}^{(n+1) / n}\right] \\
\text { for } n \neq-1, t_{\mathrm{r}}>0, t_{\mathrm{R}}>0
\end{gathered}
$$



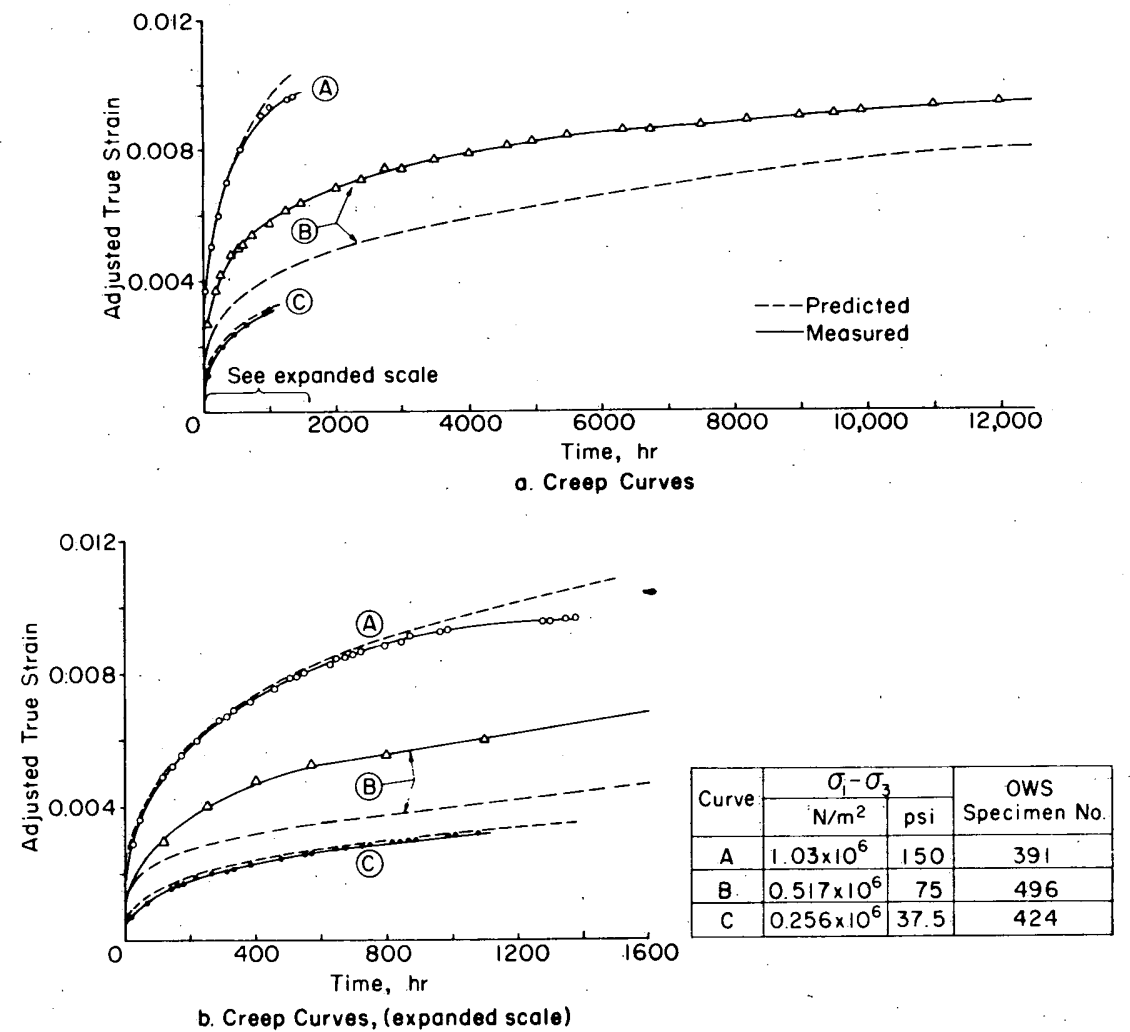

Figure 10. Measured compared with predicted creep strain for Ottawa sand. $A, B$ and $C$ indicate different specimens of sand.

and

$$
\epsilon-\epsilon_{\mathrm{r}}=\dot{\epsilon}_{\mathrm{R}} /\left(t_{\mathrm{R}}\right)^{1 / n} \ln \left(t / t_{\mathrm{r}}\right) \quad \text { for } n=-1
$$

where $t_{\mathrm{r}}$ and $\epsilon_{\mathrm{r}}$ are convenient reference time greater than zero and corresponding strain.

For $t_{\mathrm{R}}$ and $t_{\mathrm{r}}$ taken as 1 hour, then $\dot{\epsilon}_{\mathrm{R}}=\dot{\epsilon}_{1}$ and $\epsilon_{\mathrm{r}}=\epsilon_{1}$, and eq 2 becomes

$$
\dot{\epsilon}=\epsilon_{1}(n / n+1)\left[t^{(n+1) / n}-1\right]+\epsilon_{1} \quad \text { for } n \neq-1
$$

and

$$
\dot{\epsilon}=\epsilon_{1}(\ln t)+\epsilon_{1} \quad \text { for } n=-1 \text {. }
$$

By determining values of $\dot{\epsilon}_{1}, \epsilon_{1}$ and $n$ from short term creep tests conducted under the desired stress and temperature conditions, eq 2 a provides a means for estimating the value of strain at any time. Figure 10 gives a comparison between the predicted or estimated strain and laboratory creep test data. The constants for eq $2 \mathrm{a}$ were determined from the first eight hours of each creep test. 


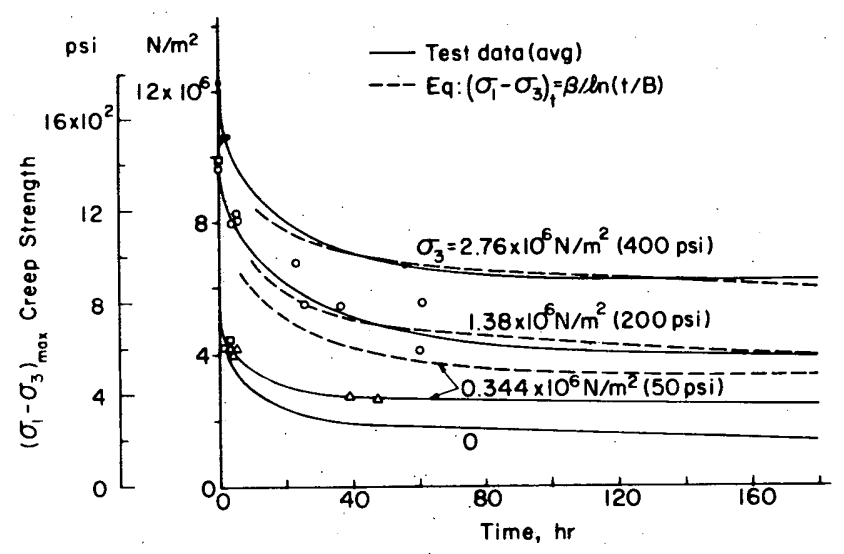

Figure 11. Creep strength vs time to failure for Ottawa sand.
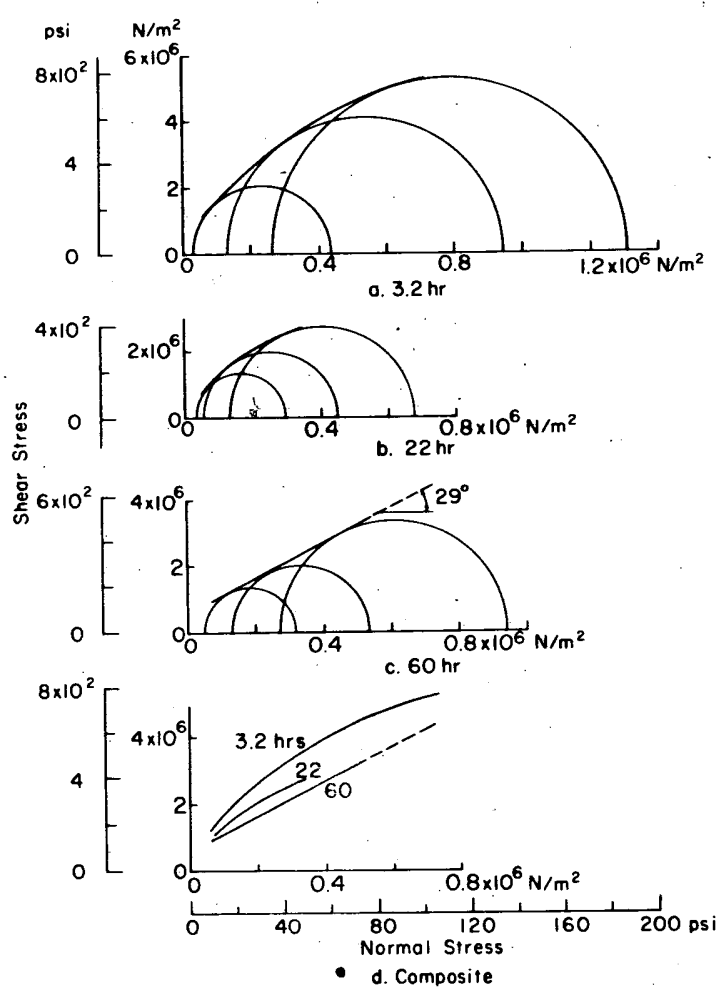

Figure 12. Mohr envelopes for creep strength of Ottawa sand.

\section{TRIAXIAL CREEP STRENGTH}

Since the soil tested in this investigation did not fail abruptly by rupture but instead deformed continuously in a plastic manner, the criterion for failure was arbitrarily taken to be the time the specimen strain reached 0.2 . Assuming a strain of 0.2 as failure, strength vs time curves for different confining pressures were obtained by plotting the time to failure against the corresponding creep strength (Fig. 11). These curves are drawn to approach asymptotically the maximum test stresses that did not result in specimen failure during the test period. Although limited data are available for each confining pressure and the data vary somewhat, especially for confining pressures of $1.38 \times 10^{6} \mathrm{~N} / \mathrm{m}^{2}(200 \mathrm{psi})$, the test results can be represented by ${ }^{10}$

$$
\sigma_{\mathrm{t}} \cong\left(\sigma_{1}-\sigma_{3}\right)_{\mathrm{t}} \simeq \beta / \mathrm{ln}(\mathrm{t} / \mathrm{B})
$$

where $\beta$ and $B$ are parameters that can be determined by short-term creep tests under the stress and temperature conditions for which estimated strengths are required. The strength variations with time predicted by eq 3 are represented by dashed lines in Figure 11 for comparison with the test data for relatively short creep tests.

Mohr envelopes representing creep strengths for different times after application of constant axial stress are shown in Figure 12. The curved envelopes for the shorter periods of time suggest that the strength of the ice crystals and the friction between the ice crystals dominate the strength of the soil mass much in the manner indicated in the constant rate of applied strain 
tests previously described. The envelopes for the 60-hour period at reduced constant axial stress approach a straight line with an angle of internal friction of about $29^{\circ}$. As mentioned earlier, this angle is near that of unfrozen Ottawa sand, thus implying that friction between the sand grains dominates the strength of the soil mass at the longer test times. These envelopes suggest that at lower applied axial stresses, time is available for the ice to creep from between the sand grains and allow the development of an increase in the number of soil grain contacts and firmer grain-tograin contacts. The frictional resistance of the sand grains would thus tend to dominate the strengths of the sand over long periods. It is hypothesized that the long term, ultimate creep strengths of frozen sands can be estimated by drained triaxial tests on sands under the same stress conditions and unit weights as those of the in-situ material. For practical purposes Mohr-Coulomb's expression

$$
\tau=C+\sigma_{\mathrm{n}} \tan \phi
$$

where $C=$ cohesion

$\sigma_{\mathrm{n}}=$ normal stress

$\phi=$ angle of internal friction for the sand

would apply.

It is emphasized that eq 4 should be applied only to sands with low ice contents and porosity of about $37 \%$ or less. Soils with high ice content and porosity can behave in a viscous manner. ${ }^{6}$

\section{SUMMARY AND CONCLUSIONS}

The results of this investigation based on triaxial compression tests performed on saturated frozen Ottawa sand (20-30 mesh) and polycrystalline columnar-grained ice at $-3.85^{\circ} \mathrm{C}$ show that:

1. The resistance of saturated frozen Ottawa sand in a confined stress condition can be considered as consisting of the cohesion of the ice matrix and the frictional resistance of the sand grains. These sources of strength are nearly independent of each other when the applied rate of strain is greater than $0.02 \mathrm{~min}^{-1}$. After the ice matrix has failed at a strain less than 0.01 , the soil resistance becomes a function of the normal stress and the apparent angle of the internal friction of unfrozen sand, about $30^{\circ}$.

2. For a given temperature the initial or "cohesive" strength of the frozen sand increases with the rate of applied strain and can be represented approximately by the expression

$$
\left(\sigma_{1}-\sigma_{3}\right)_{\mathrm{c}}=16.6 \times 10^{6}(\dot{\epsilon})^{0.1}
$$

where $\left(\sigma_{1}-\sigma_{3}\right)_{\mathrm{c}}=$ initial or cohesive strength

$\dot{\epsilon}=$ applied strain rate from 0.002 to $1.0 / \mathrm{min}$.

3. The rate of increase in the initial shear strength of saturated frozen Ottawa sand and poly crystalline columnar-grained ice decreases with increasing confining pressure. At the higher confining pressures used in this investigation, the initial shear strength is nearly independent of confining pressure at rates of applied strain greater than 0.02 .

4. The short-term (periods of up to 100 hours) creep strength of frozen Ottawa sand can be represented by Vyalov's ${ }^{10}$. strength equation:

$$
\sigma_{\mathrm{t}} \cong\left(\sigma_{1}-\sigma_{3}\right)_{\mathrm{t}} \cong \beta / \ln (t / B)
$$


5. For low axial (deviator) stress levels, the creep strain rate can be represented by the empirical expression:

$$
\begin{aligned}
& \dot{\epsilon} / \dot{\epsilon}_{\mathrm{R}}=\left(t / t_{\mathrm{R}}\right)^{1 / n} \\
& \dot{\epsilon}=\left[\dot{\epsilon}_{\mathrm{R}} / t / R^{\ln }\right](+)^{1 / n}
\end{aligned}
$$

for a given constant stress and temperature condition.

6. For low axial (deviator) stress levels, creep strain can be estimated by

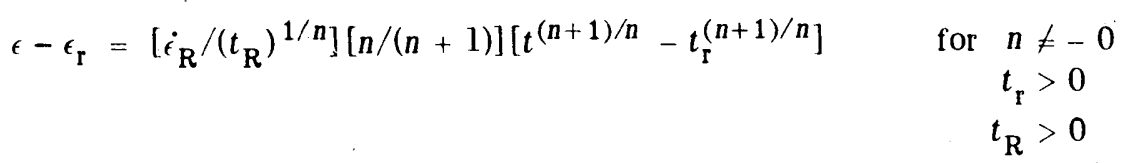

and

$$
\epsilon-\epsilon_{\mathrm{r}}=\dot{\epsilon}_{\mathrm{R}} /\left(t_{\mathrm{R}}\right)^{1 / \mathrm{n}} \ln \left(t / t_{\mathrm{r}}\right) \quad \text { for } n=-1
$$

for a constant stress and temperature condition. At higher axial stress levels where the creep curve approaches a straight line, clearly this equation is not applicable.

7. It is hypothesized that the long-term ultimate creep strength of saturated frozen sand with a porosity of $37 \%$ or less is a function of the angle of internal friction of the sand which could be determined through triaxial tests on freely drained unfrozen sand.

\section{LITERATURE CITED}

1. Andersland, O.B. and W. Akili (1967) Stress effect on creep rates of frozen clay. Geotechnique, vol. 17, p. 27-39.

2. Andersland, O.B. and I. AlNouri (1970) Time-dependent strength behavior of frozen soils. Journal of Soil Mechanics and Foundations Division, American Society of Civil Engineers (ASCE), vol. 96, no. SMA, p. 1249-1265.

3. Muguruma, J. (1969) Effects of surface condition on the mechanical properties of ice crystals. British Journal of Applied Physics (Journal of Physics D), ser. 2, no. 11, p. 1517-1525.

4. Sanger, F.J. and C.W. Kaplar (1963) Plastic deformation of frozen soils in uncon: fined compression. Proceedings, First Permafrost International Conference, Building Research Advisory Board, National Academy of Sciences.

5. Sayles, F.H. (1968) Creep of frozen sands. U.S. Army Cold Regions Research and Engineering Laboratory (USA CRREL), Technical Report 190. AD 680902.

6. Thompson, E.G. and F.H. Sayles (1972) In-situ creep analysis of room in frozen soil. Journal of Soil Mechanics and Foundations Division, ASCE, vol. 98, no. SM9, Proc. Paper 9202, p. 899-915.

7. Tsytovich, N.A. and M.I. Sumgin (1957) Principles of mechanics of frozen ground. U.S. Army Snow, Ice and Permafrost Research Establishment (USA SIPRE), Translation 19 (out of print). 
8. USA SIPRE (1952) Investigation of description, classification and strength properties of frozen soils. Prepared by U:S. Army Arctic Construction and Frost Effects Laboratory (USA ACFEL), U.S. Army Corps of Engineers for USA SIPRE, Report 8.

9. Vyalov, S.S. (1959) Rheological properties and bearing capacity of frozen soils. USSR Academy of Sciences. (Also USA SIPRE, Translation 74, 1963. AD 481856.)

10. Vyalov, S.S. (1963) Rheology of frozen soils. Proceedings, First Permafrost International Conference, Building Research Advisory Board, National Academy of Sciences.

11. Vyalov, S.S. and S. Tsytovich (1955) Cohesion of frozen soils. Doklady Akademiia Nauk, 104, no. 4, p. 527-529.

12. Young, R.N. (1963) Soil freezing consideration in frozen soil strength. Proceedings, First Permafrost International Conference, Building Research Advisory Board, National Academy of Sciences. 
Table AI. Triaxial test - constant rate of applied strain, Ottawa sand (20-30).

Temperature $=25^{\circ} \mathrm{F}\left(-3.89^{\circ} \mathrm{C}\right)$

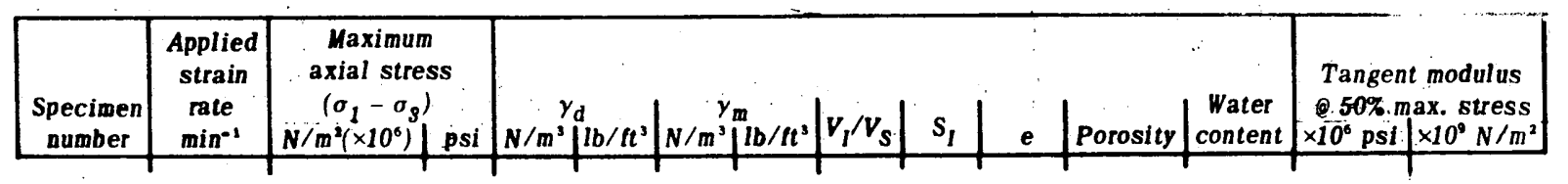

\section{$\sigma_{8} \neq 0.689 \times 10^{\circ} \mathrm{N} / \mathrm{m}^{2}$ (100 p81)}

\begin{tabular}{llr}
317 & 0.0036 & 8.30 \\
$299^{*}$ & 0.0045 & 7.92 \\
$288^{*}$ & 0.0050 & 9.00 \\
$280^{*}$ & 0.017 & 11.78 \\
\hline $278^{*}$ & 0.023 & 11.30 \\
$293^{*}$ & 0.026 & 12.18 \\
$281^{*}$ & 0.14 & 12.75 \\
$295^{*}$ & 0.14 & 13.30 \\
264 & 0.16 & 12.40 \\
265 & 0.17 & 14.55 \\
434 & 0.377 & 13.20 \\
435 & 0.399 & 13.20 \\
433 & 0.553 & 13.71
\end{tabular}

$\begin{array}{llllllllll}1181 & 1635 & 102.1 & 1987 & 124.1 & 0.631 & 98.8 & 0.638 & 0.389\end{array}$ $\begin{array}{llllllllll}1147 & 1684 & 105.2 & 2043 & 127.6 & 0.622 & 105.6 & 0.590 & 0.371\end{array}$ $\begin{array}{llllllllll}1307 & 1645 & 102.7 & 2016 & 125.9 & 0.659 & 104.9 & 0.628 & 0.386\end{array}$ $\begin{array}{llllllllll}1707 & 1643 & 102.6 & 2016 & 125.9 & 0.664 & 105.4 & 0.630 & 0.387\end{array}$ $\begin{array}{llllllllll}1679 & 1652 & 103.2 & 2024 & 126.4 & 0.656 & 105.7 & 0.621 & 0.383\end{array}$ $\begin{array}{lllllllll}1768 & 1673 & 104.5 & 2037 & 127.2 & 0.635 & 105.8 & 0.601 & 0.375\end{array}$ $\begin{array}{llllllllll}1845 & 1654 & 103.3 & 2021 & 126.2 & 0.647 & 104.4 & 0.618 & 0.382\end{array}$ $\begin{array}{llllllllll}1928 & 1692 & 105.7 & 2040 & 127.4 & 0.601 & 103.2 & 0.582 & 0.368\end{array}$ $\begin{array}{llllllllll}1798 & 1661 & 103.7 & 2002 & 125.0 & 0.600 & 98.0 & 0.612 & 0.380\end{array}$ $\begin{array}{lllllllll}2107 & 1654 & 103.3 & 2000 & 124.4 & 0.611 & 98.7 & 0.619\end{array}$ $\begin{array}{llllllll}1920 & 1678 & 104.8 & 2015 & 125.8 & 0.583 & 98.8 & 0.590\end{array}$ $\begin{array}{lllllllll}1920 & 1672 & 104.4 & 2010 & 125.5 & 0.588 & 98.7 & 0.596\end{array}$ $\begin{array}{llllllll}1990 & 1675 & 104.6 & 2013 & 125.7 & 0.587 & 99.0 & 0.592\end{array}$

0.382

0.371

0.373

0.372

$\begin{array}{rlr}0.216 & 0.250 & 1.72 \\ 0.213 & 0.227 & 1.56 \\ 0.225 & 0.208 & 1.43 \\ 0.227 & 3.50 & 21.45 \\ 0.225 & 0.556 & 3.82 \\ 0.217 & & \\ 0.221 & 0.818 & 5.64 \\ 0.206 & 0.708 & 4.88 \\ 0.205 & 0.666 & 4.58 \\ 0.209 & & \\ 0.200 & 4.76 & 32.8 \\ 0.202 & 7.46 & 51.3 \\ 0.201 & 2.00 & 13.8\end{array}$

$\sigma_{8}=1.379 \times 10^{6} \mathrm{~N} / \mathrm{m}^{2}(200 \mathrm{psi})$

\begin{tabular}{|c|c|c|c|c|c|c|c|c|c|c|c|c|c|c|}
\hline 304* & 0.0182 & 9.75 & 1411 & 1600 & 99.9 & 1984 & 123.9 & 0.701 & 104.2 & 0.673 & 0.402 & C.240 & 0.263 & 1.81 \\
\hline 308 & 0.0182 & 9.85 & 1425 & 1616 & 100.9 & 1974 & 124.5 & 0.655 & 99.6 & 0.658 & 0.397 & 0.224 & 0.270 & 1.86 \\
\hline 313 & 0.0372 & 8.75 & 1265 & 1620 & 101.3 & 1979 & 123.0 & 0.648 & 49.3 & 0.653 & 0.395 & 0.192 & 0.192 & 1.32 \\
\hline 303 & 0.038 & 10.15 & 1571 & 1621 & 101.2 & 1978 & 123.5 & 0.644 & 48.8 & 0.652 & 0.395 & 0.220 & 0.333 & 2.29 \\
\hline 298* & 0.040 & 9.7 & 1404 & 1606 & 100.3 & 1986 & 124.0 & 0.091 & 103.5 & 0.668 & 0.400 & 0.236 & 0.277 & 1.91 \\
\hline 297 & 0.162 & 12.65 & 1836 & 1638 & 102.3 & 1991 & 124.3 & 0.627 & 98.8 & 0.634 & 0.388 & 0.214 & 0.323 & 2.22 \\
\hline 316 & 0.163 & 12.2 & 1775 & 1638 & 102.3 & 1929 & 124.2 & 0.628 & 98.7 & 0.635 & 0.388 & & 0.327 . & 2.25 \\
\hline 314 & 0.164 & 11.8 & 1716 & 1662 & 103.8 & 2005 & 125.2 & 0.601 & 98.4 & 0.611 & 0.379 & 0.206 & 0.323 & 2.22 \\
\hline 414 & 0.770 & 13.85 & 2010 & 1656 & 103.4 & 2002 & 125.0 & 0.605 & 98.2 & 0.611 & 0.379 & 0.208 & 2.09 & 14.42 \\
\hline 410 & 0.772 & 15.98 & 2310 & 1690 & 105.5 & 2007 & 125.3 & 0.547 & 94.4 & 0.579 & 0.367 & 0.188 & 3.31 & 22.85 \\
\hline 16 & 0.772 & 16.62 & 2420 & 1634 & 102.0 & 1970 & 123.0 & 0.600 & 94.8 & 0.634 & 0.388 & 0.206 & 2.22 & 15.42 \\
\hline
\end{tabular}

$\sigma_{3}=2.758 \times 10^{6} \mathrm{~N} / \mathrm{m}^{2}(400 \mathrm{psi})$

$\begin{array}{llllllllllllllll}321 & 0.00216 & 10.65 & 1555 & 1680 & 104.9 & 2017 & 126.0 & 0.588 & 98.9 & 0.594 & 0.373 & 0.201 & 0.195 & 1.34 \\ 323 & 0.00268 & 8.40 & 1220 & & & & & & & & & & & \\ 305 & 0.00295 & 10.15 & 1475 & 1651 & 103.1 & 1998 & 124.8 & 0.614 & 98.9 & 0.621 & 0.383 & 0.210 & 0.2786 & 1.92 \\ 310 & 0.0034 & 8.20 & 1175 & 1645 & 102.7 & 1997 & 124.7 & 0.625 & 99.5 & 0.628 & 0.386 & 0.214 & 0.1045 & 0.72 \\ 307 & 0.019 & 11.9 & 1233 & 1622 & 101.3 & 1983 & 123.8 & 0.649 & 99.7 & 0.651 & 0.394 & 0.222 & 0.3091 & 2.13 \\ 311^{*} & 0.0192 & 12.6 & 1829 & 1588 & 99.2 & 1987 & 124.1 & 0.732 & 106.9 & 0.685 & 0.407 & 0.251 & 0.287 & 1.98 \\ 412^{*} & 0.105 & 16.0 & 2320 & 1634 & 102.1 & 2002 & 125.0 & 0.655 & 102.7 & 0.638 & 0.390 & 0.224 & 3.50 & 21.45 \\ 411 & 0.110 & 15.7 & 2284 & 1654 & 103.3 & 2003 & 125.1 & 0.618 & 99.8 & 0.619 & 0.382 & 0.211 & \text { No Data } \\ 320 & 0.160 & 13.65 & 1988 & 1659 & 103.6 & 2005 & 125.2 & 0.609 & 99.3 & 0.614 & 0.380 & 0.209 & 0.30 & 2.07 \\ 413 & 0.608 & 18.0 & 2610 & 1670 & 104.3 & 2008 & 125.4 & 0.591 & 98.8 & 0.598 & 0.374 & 0.203 & 1.72 & 11.84 \\ 417 & 0.610 & 17.7 & 2570 & 1664 & 103.9 & 2005 & 125.2 & 0.598 & 99.0 & 0.604 & 0.376 & 0.205 & \text { Machine Error } \\ 415 & 0.956 & 17.9 & 2600 & 1651 & 103.1 & 1992 & 124.4 & 0.605 & 98.2 & 0.616 & 0.381 & 0.208 & 1.692 & 11.64\end{array}$

$\sigma_{3}=5.516 \times 10^{6} \mathrm{~N} / \mathrm{m}^{2}(800 \mathrm{psi})$

$\begin{array}{llllllllllllllll}449 & 0.0035 & 10.0 & 1450 & 1675 & 104.6 & 2011 & 125.6 & 0.585 & 98.7 & 0.593 & 0.372 & 0.201 & 0.500 & 3.43 \\ 446 & 0.0038 & 10.45 & 1520 & 1777 & 111.0 & 2017 & 126.0 & 0.392 & 98.4 & 0.500 & 0.334 & 0.135 & 0.905 & 6.23 \\ 438 & 0.0040 & 10.45 & 1520 & 1677 & 104.7 & 2013 & 125.7 & 0.586 & 99) 0 & 0.592 & 0.372 & 0.201 & 0.583 & 4.01 \\ 450 & 0.00402 & 10.45 & 1520 & 1683 & 105.1 & 2017 & 126.0 & 0.578 & 98.8 & 0.585 & 0.369 & 0.199 & 0.860 & 5.90 \\ 428 & 0.014 & 11.70 & 1700 & 1669 & 104.2 & 2008 & 125.4 & 0.691 & 98.8 & 0.598 & 0.374 & 0.203 & 0.660 & 4.54\end{array}$

* Error in weighing.

t Sample destroyed.

$\gamma_{\mathrm{d}}=$ dry unit weight; $\gamma_{\mathrm{m}}=$ mass unit weight; $V_{\mathrm{l}} / V_{\mathrm{S}}=$ vol. of ice/vol. of soil grains; $s_{1}=$ percent of voids filled with ice. $\mathrm{e}=$ void ratio. 
Table AI (cont'd). Triaxial test - constant rate of applied strain, Ottawa sand (20-30). Temperature $=25^{\circ} \mathrm{F}\left(-3.89^{\circ} \mathrm{C}\right)$

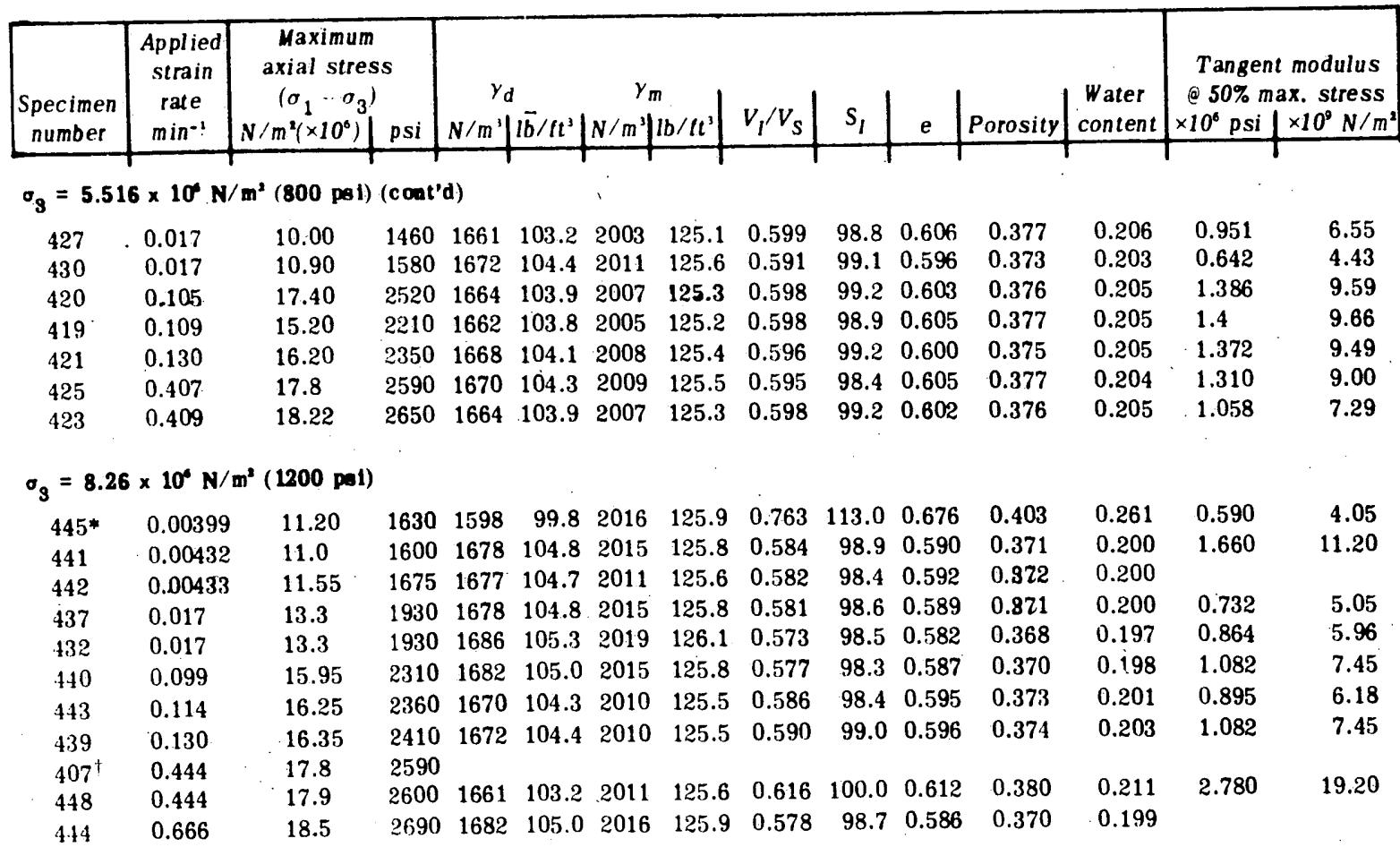

* Error in weighing.

+ Sample destroyed.

$\gamma_{\mathrm{d}}=$ dry unit weight; $y_{\mathrm{m}}=$ mass unit weight; $V_{\mathrm{I}} / V_{\mathrm{S}}=$ vol. of ice/vol. of soil grains: $\mathrm{S}_{\mathrm{I}}=$ percent of voids filled with ice, e void ratio. 
Table AII. Triaxial creep tests, Ottawa sand (20-30).

Temperature $=25^{\circ} \mathrm{F}\left(-3.89^{\circ} \mathrm{C}\right)$

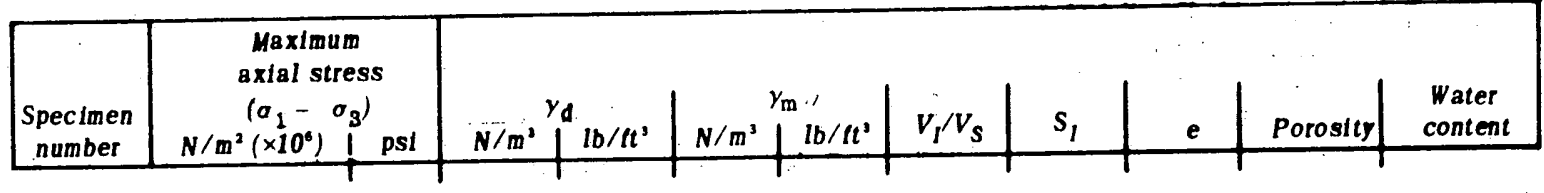

$\sigma=2.768 \times 10^{6} \mathrm{~N} / \mathrm{m}^{2}(400 \mathrm{pel})$

$389 \quad 11.03 \quad 1600$

478* $\quad 6.894 \quad 1000$

$394 \quad 5.516 \quad 800$

$393 \quad 5.516 \quad 800$

$474 \quad 4.14 \quad 600$

$454 \quad 2.758 \quad 400$

$\sigma_{g}=1.379 \times 10^{6} \mathrm{~N} / \mathrm{m}^{2}(200 \mathrm{pet})$

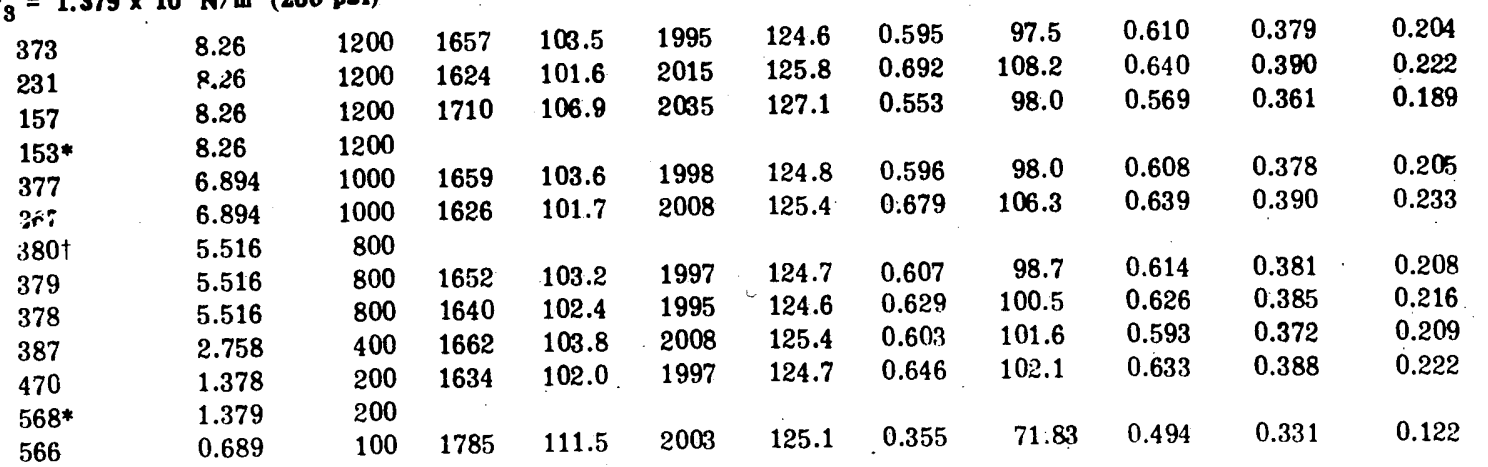

$\sigma_{3}=0.51 \times 10^{6} \mathrm{~N} / \mathrm{m}^{2}(75 \mathrm{ps} 1)$

\begin{tabular}{|c|c|c|c|c|c|c|c|c|c|c|c|c|}
\hline 476 & & 4.14 & 600 & 1668 & 104.1 & 1998 & 124.8 & 0.579 & 96.4 & 0.601 & 0.375 & 0.199 \\
\hline 472 & . & 4.14 & 600 & 1651 & 103.1 & 1997 & 124.7 & 0.612 & 99.3 & 0.616 & 0.381 & 0.210 \\
\hline 466 & & 4.14 & 600 & 1666 & 104.0 & 1998 & 124.8 & 0.583 & 96.8 & 0.602 & 0.376 & 0.200 \\
\hline 482 & & 2.758 & 400 & 1649 & 103.0 & 1995 & 124.6 & 0.611 & 98.9 & 0.618 & 0.382 & 0.210 \\
\hline 465 & & 1.378 & 200 & 1670 & 104.3 & 1998 & 124.8 & 0.573 & 95.8 & 0.598 & 0.374 & 0.197 \\
\hline 391 & & 1.35 & 150 & 1684 & 105.2 & 2017 & 126.0 & 0.574 & 98.4 & 0.583 & 0.368 & 0.197 \\
\hline 461 & & 0.517 & 75 & 1669 & 104.2 & 1992 & 124.4 & 0.565 & 94.3 & 0.599 & 0.375 & 0.194 \\
\hline 392 & & 0.517 & 75 & 1680 & 104.9 & 2015 & 125.8 & 0.578 & 98.4 & 0.588 & 0.370 & 0.199 \\
\hline 463 & & 1.378 & 200 & 1678 & 104.8 & 1997 & 124.7 & 0.551 & 93.5 & 0.589 & 0.371 & 0.189 \\
\hline 496 & & 0.517 & 75 & 1657 & 103.5 & 2004 & 125.2 & 0.610 & 100.10 & 0.609 & 0.379 & 0.210 \\
\hline 429 & & 0.258 & 375 & 1672 & 104.4 & 2008 & 125.4 & 0.585 & 98.2 & 0.596 & 0.374 & 0.201 \\
\hline 424 & & 0.258 & 375 & 1735 & 108.2 & 2002 & 125.0 & 0.453 & 83.9 & 0.540 & 0.351 & 0.156 \\
\hline$\sigma_{3}=0$ & 7 & V/ & & & & & & & & & & \\
\hline 473 & & 4.14 & 600 & 1661 & 103.7 & 1998 & 124.8 & 0.594 & 97.9 & 0.607 & 0.378 & 0.204 \\
\hline 471 & & 4.14 & 600 & 1657 & 103.5 & 1995 & 124.6 & 0.595 & 97.5 & 0.610 & 0.379 & 0.204 \\
\hline 487 & & 2.758 & 400 & 1672 & 104.4 & 1998 & 124.8 & 0.570 & 95.6 & 0.596 & 0.373 & 0.196 \\
\hline 479 & & 2.758 & 400 & 1662 & 103.8 & 2008 & 125.4 & $0.604^{\circ}$ & 99.8 & 0.605 & 0.377 & 0.207 \\
\hline 266 & & 1.72 & 250 & 1670 & 104.3 & 1998 & 124.8 & 0.577 & 95.45 & 0.604 & 0.377 & 0.197 \\
\hline $262 \dagger$ & & 1.72 & 250 & & & & & & & & & \\
\hline 350 & & 1.378 & 200 & 1654 & 103.3 & 1998 & 124.8 & 0.604 & 98.6 & 0.613 & 0.380 & 0.207 \\
\hline 571 & & 1.379 & 200 & 1668 & 104.2 & 2000 & 124.9 & 0.579 & 96.68 & 0.599 & 0.374 & 0.199 \\
\hline 567 & & 1.379 & 200 & 1641 & 102.5 & 1961 & 122.5 & 0.568 & 90.83 & 0.625 & 0.385 & 0.195 \\
\hline 553 & . & 0.689 & 100 & 1686 & 105.3 & 2001 & 125.0 & 0.545 & 93.67 & 0.582 & 0.368 & 0.187 \\
\hline 352 & & 0.517 & 75 & 1661 & 103.7 & 2000 & 124.9 & 0.595 & 98.2 & 0.606 & 0.377 & 0.204 \\
\hline
\end{tabular}

* Weighing error.

† Sample destroyed.

$\gamma_{\mathrm{d}}=$ dry unit weight; $\gamma_{\mathrm{m}}=$ mass unit weight; $V_{\mathrm{I}} / V_{\mathrm{S}}=$ vol. of ice/vol. of soil grains; $S_{\mathrm{I}}=$ percent of voids filled with ice:

$e=$ void ratio. 
Table AII (cont'd). Triaxial creep tests, Ottawa sand (20-30).

Temperature $=25^{\circ} \mathrm{F}\left(-3.89^{\circ} \mathrm{C}\right)$

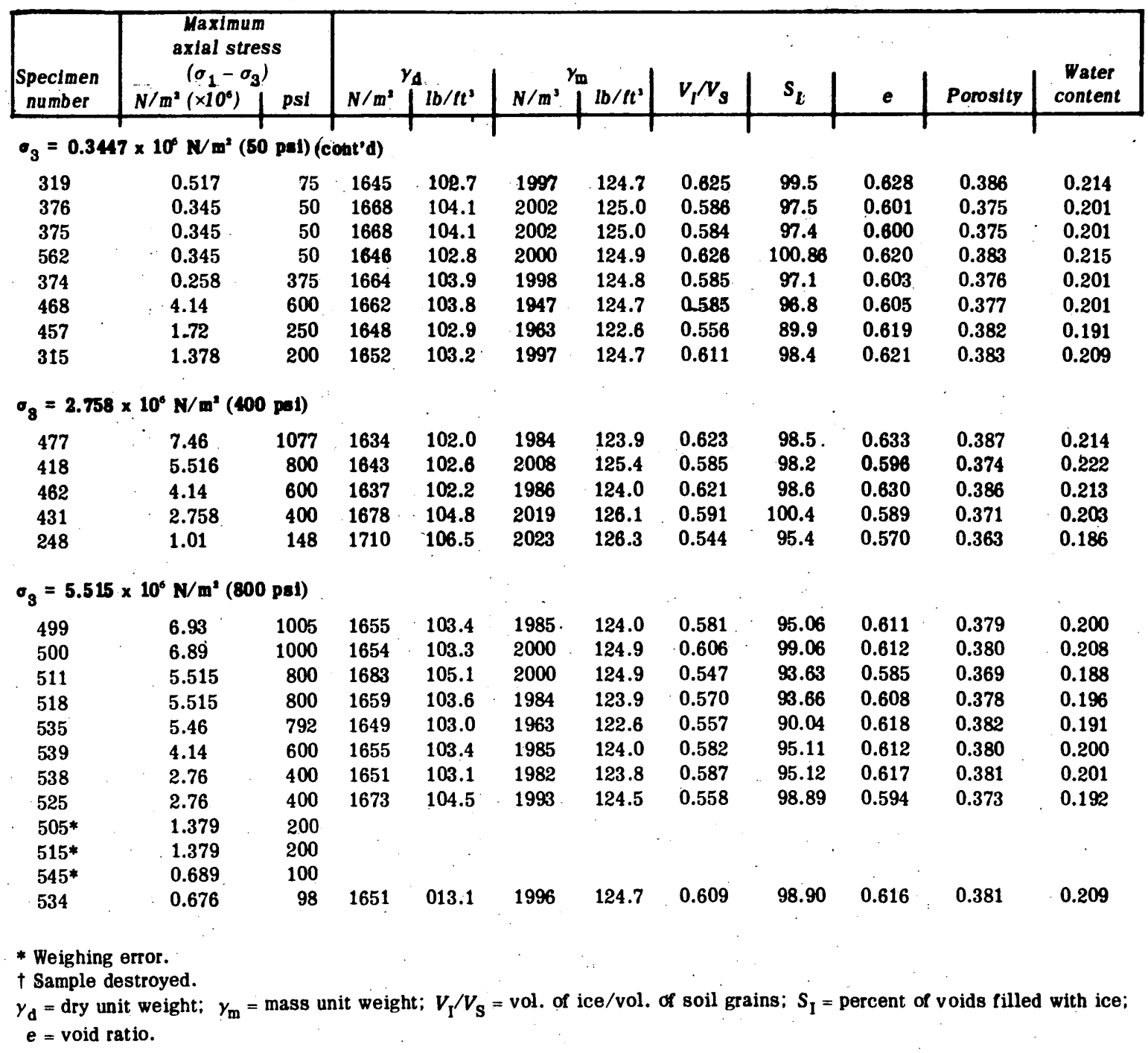


APPENDIX B: TRIAXIAL TEST STRESS-STRAIN CURVES

Saturated frozen Ottawa sand $(20-30 \mathrm{mesh})$ at $25^{\circ} \mathrm{F}\left(-3.89^{\circ} \mathrm{C}\right)$. Confining pressures $\left(\sigma_{3}\right)$ range from 100 to $1200 \mathrm{psi}$. Rates of applied strain range from .002 to $1.67 \mathrm{~min}^{-1}$

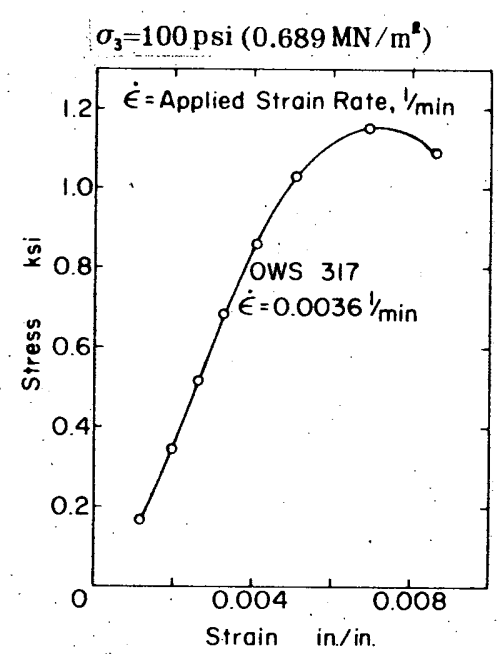

B1.

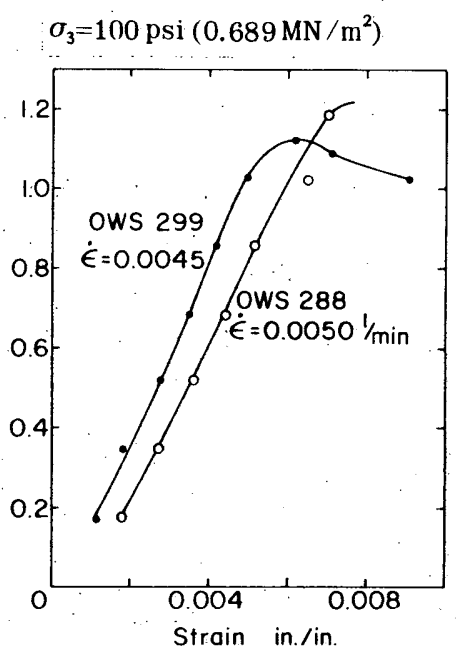

B2.

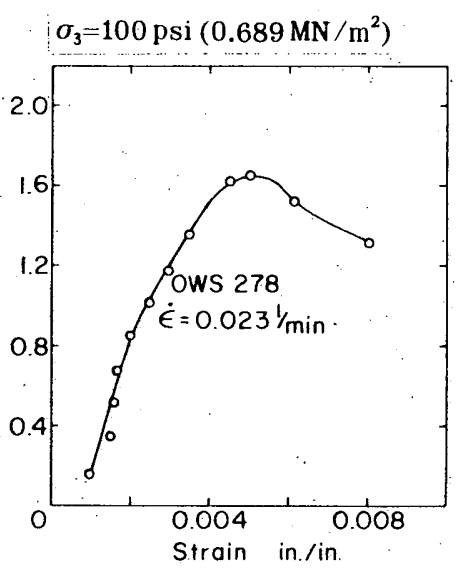

B3.

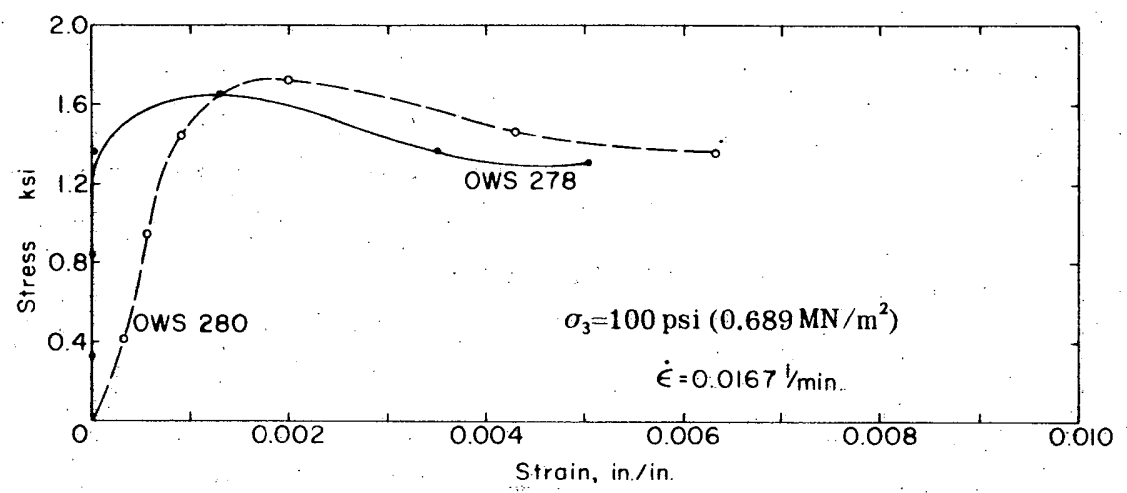

B4.

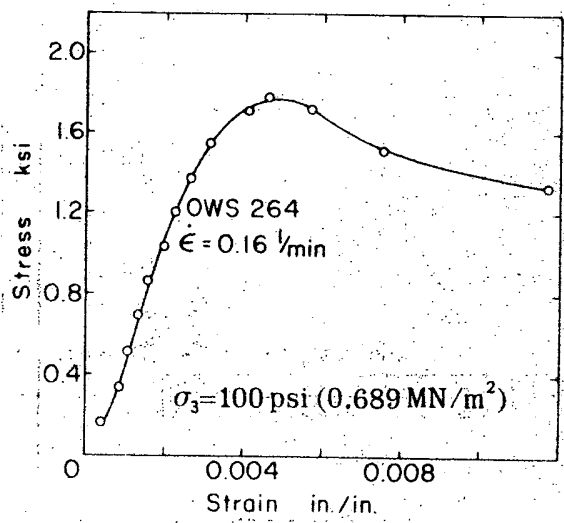

B5. 


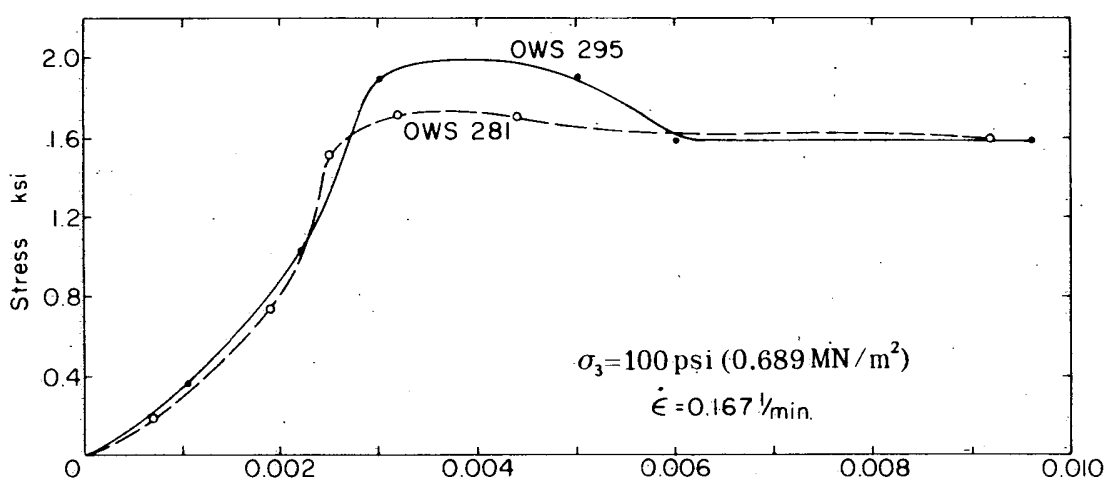

B6.
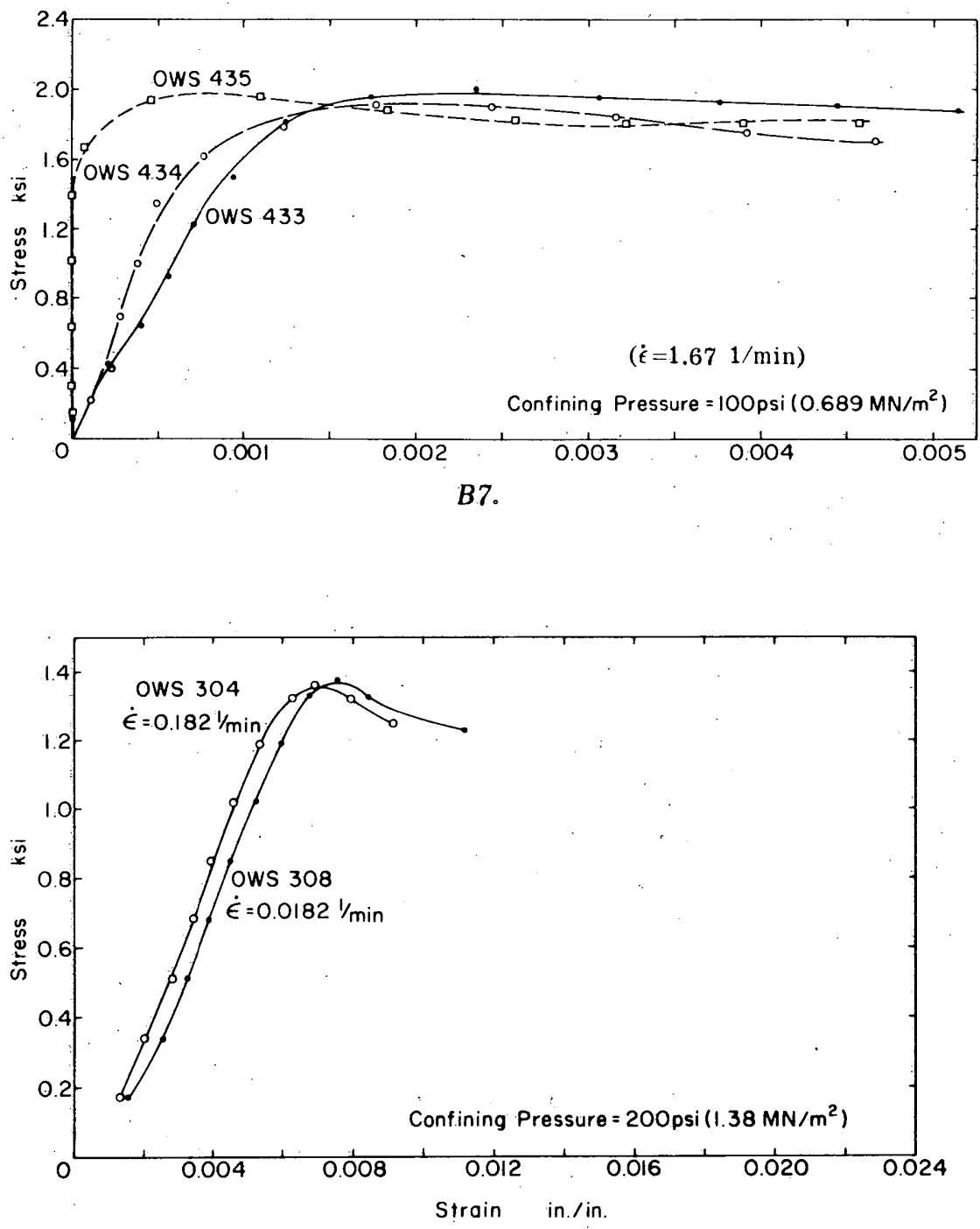

B8. 


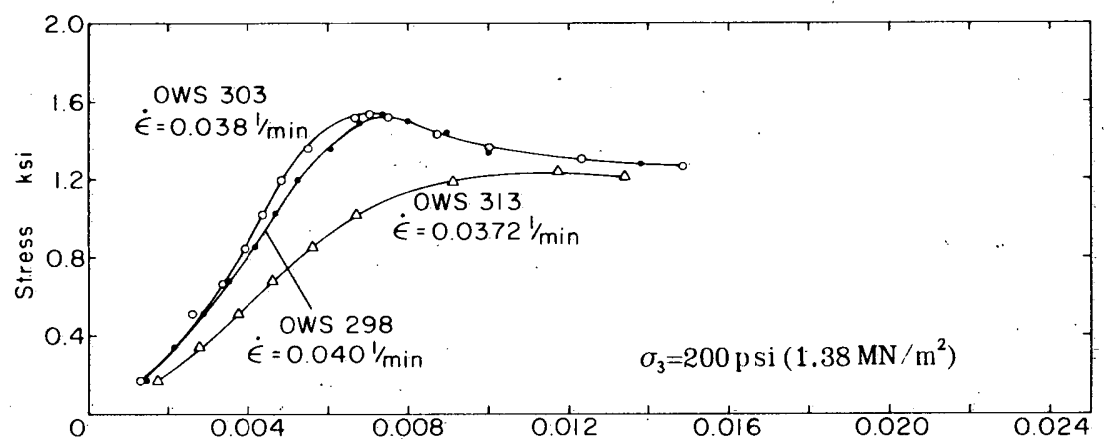

B9.
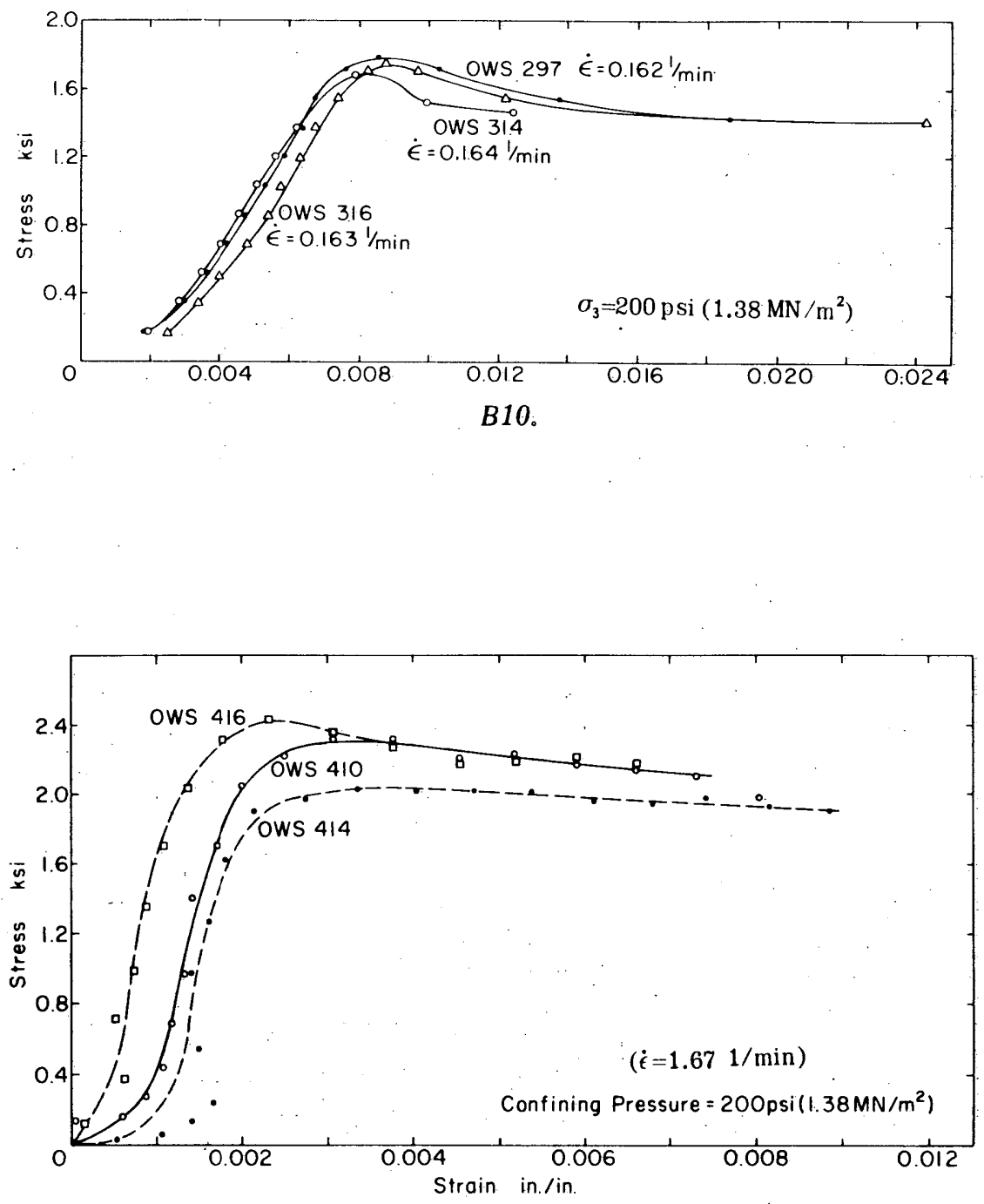

$B 11$. 

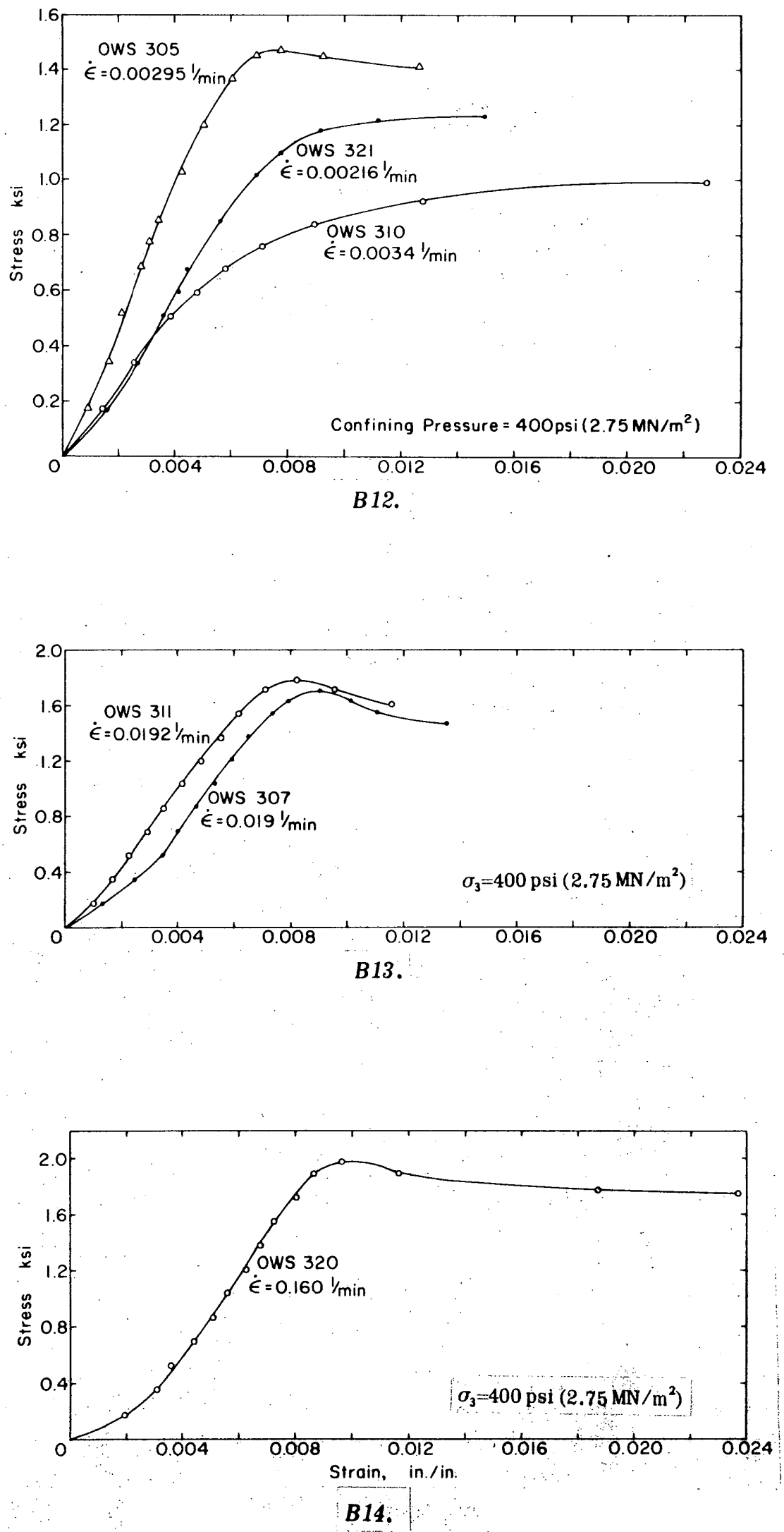

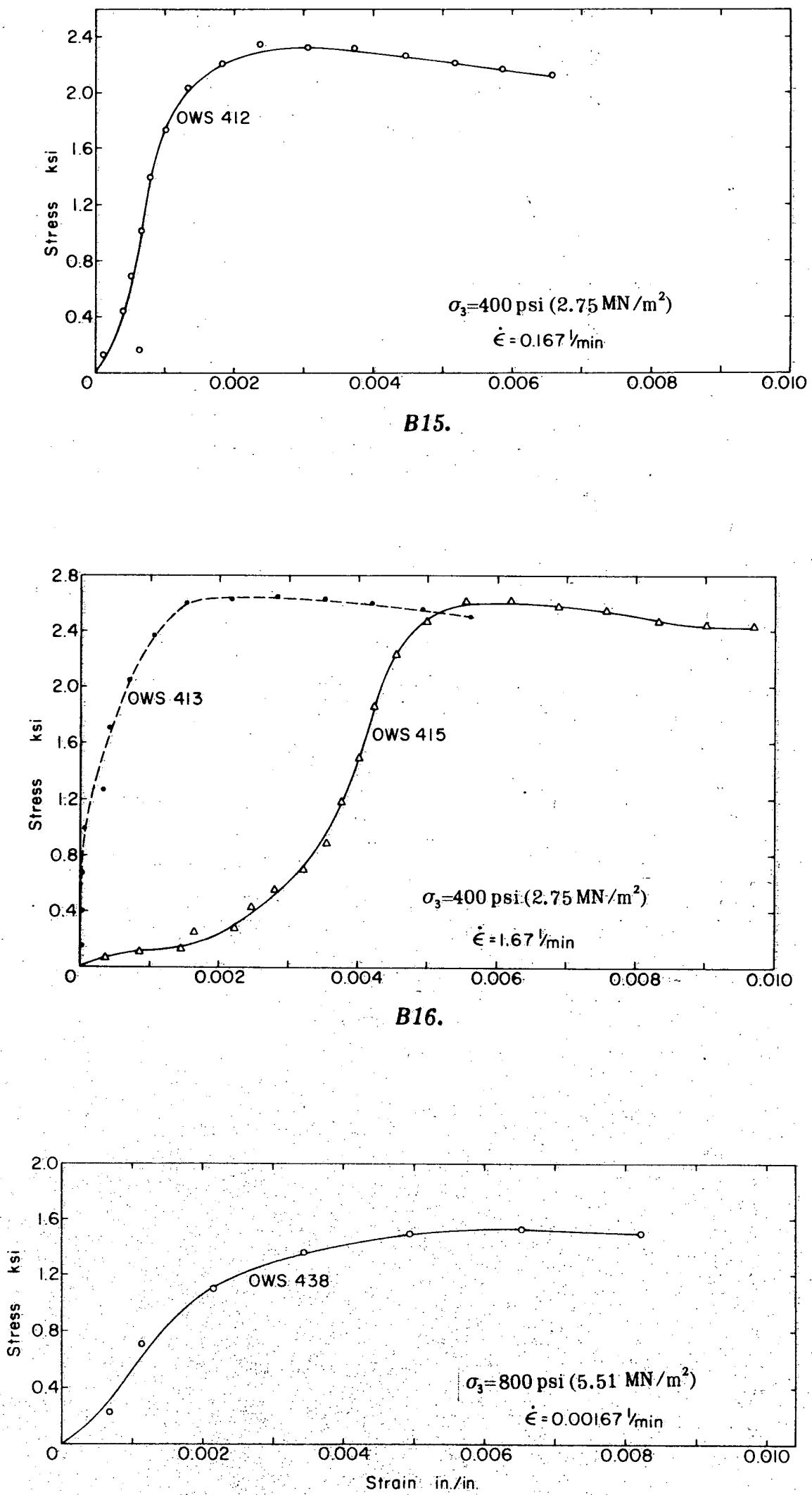

B17. 


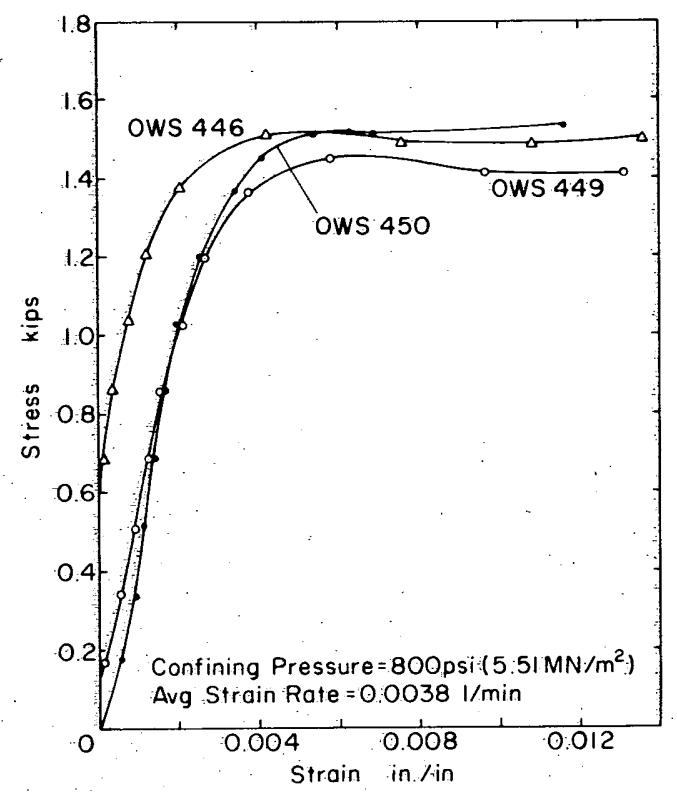

B18.
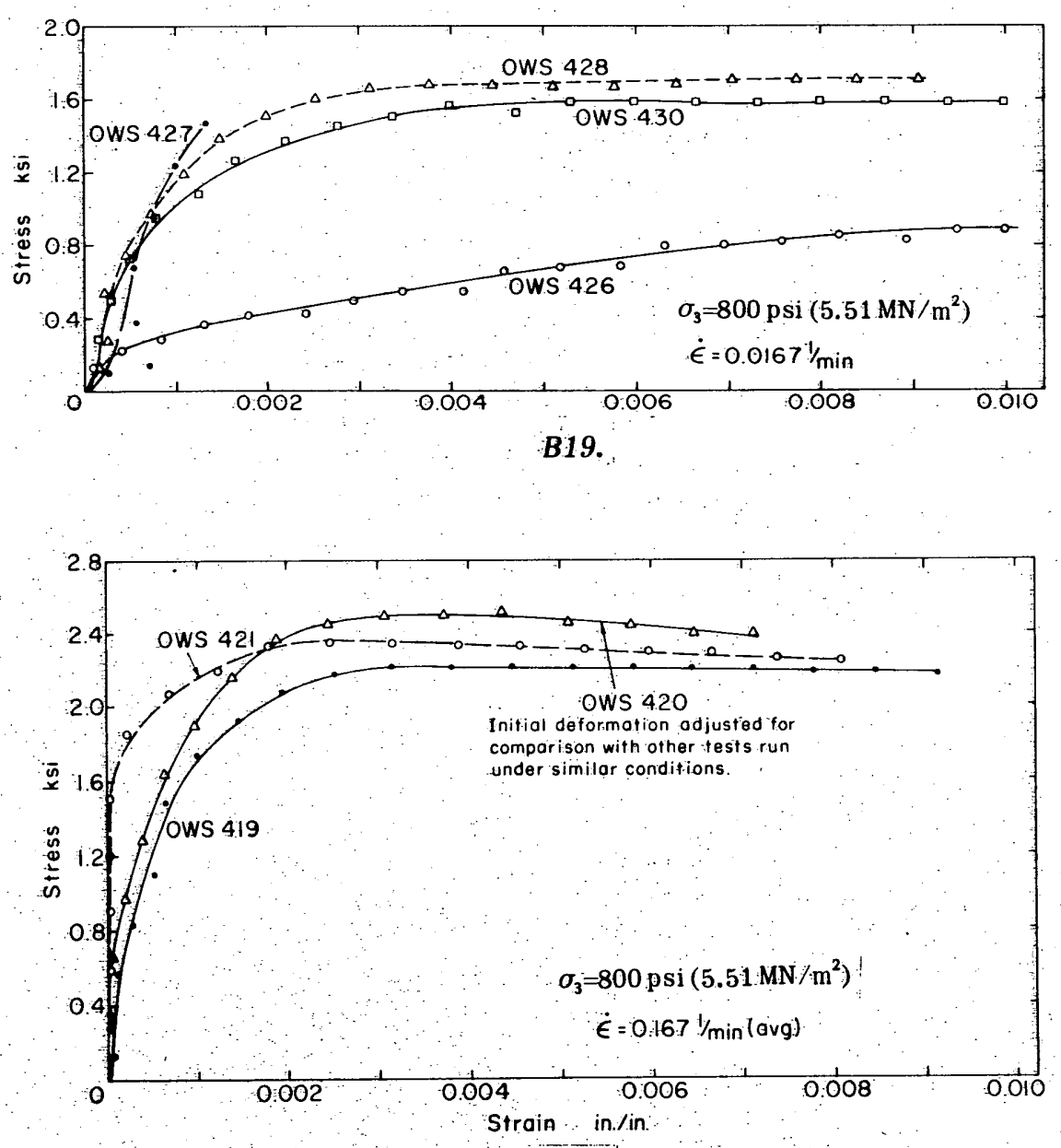

B20. 


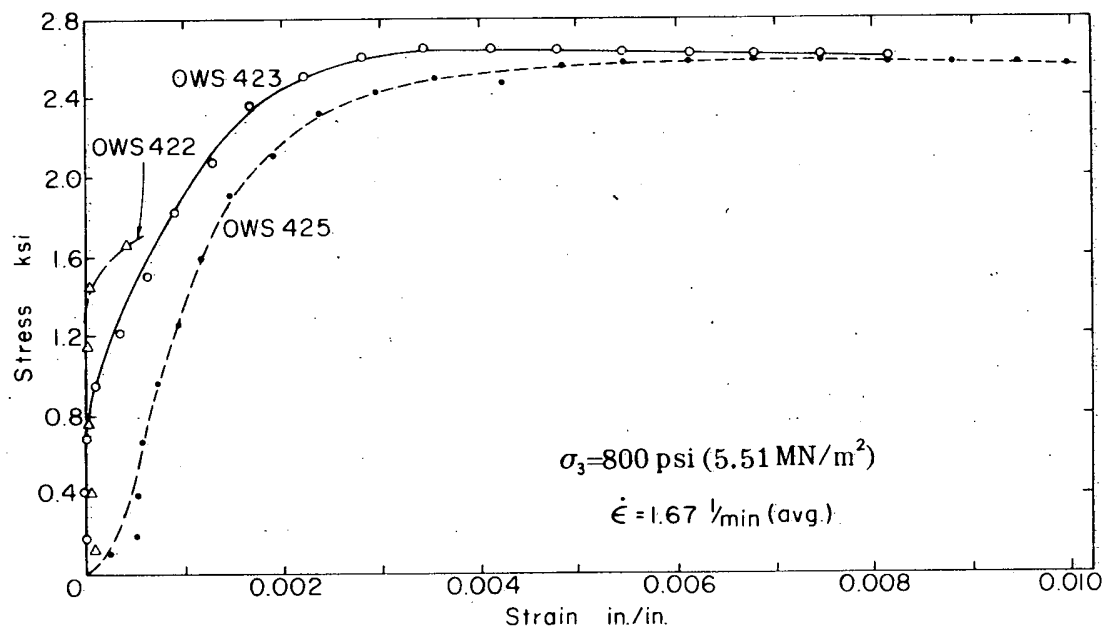

B21.

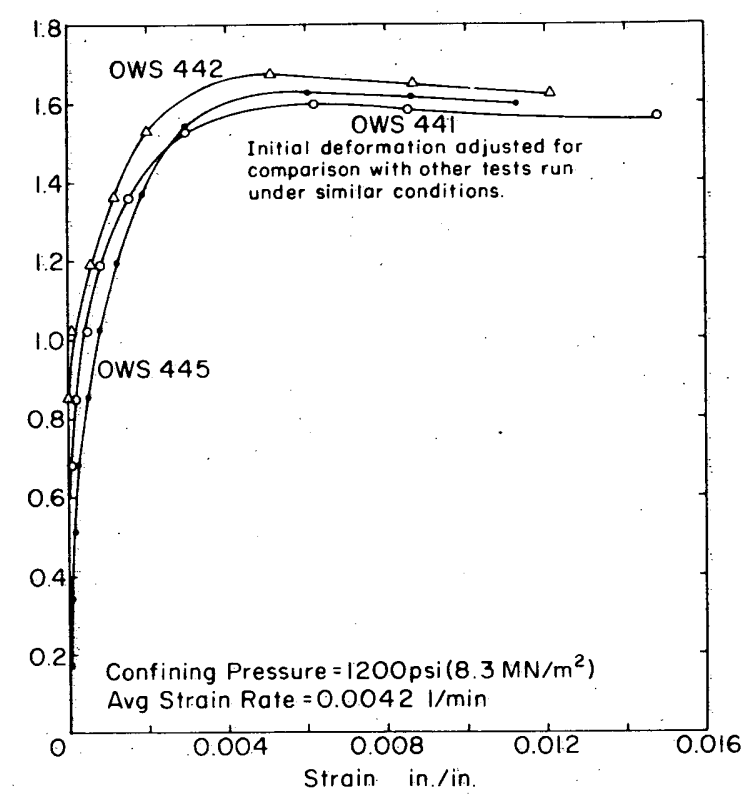

B22.

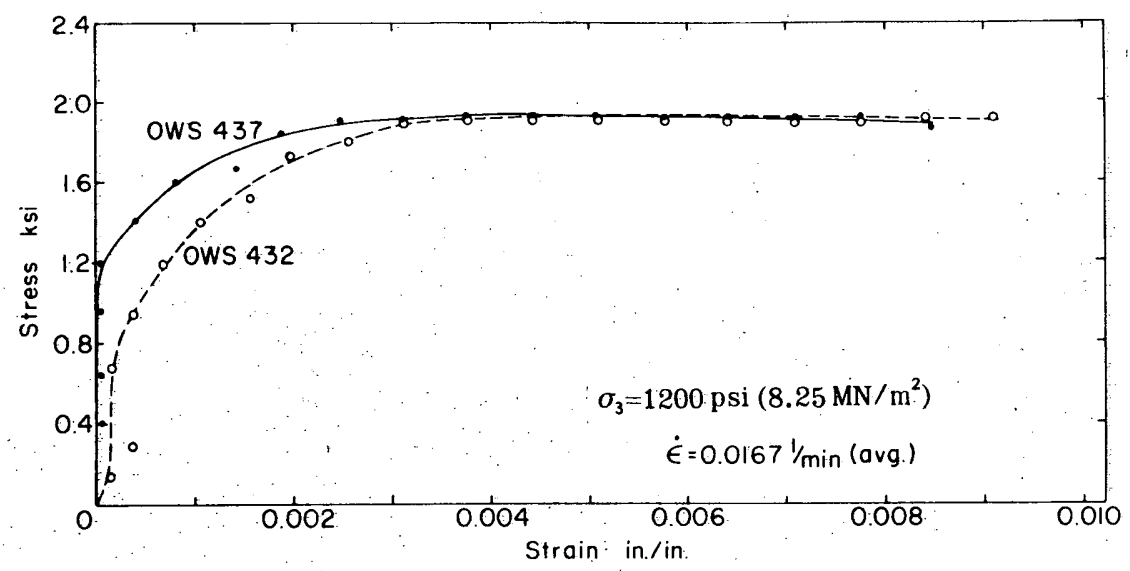

B23. 

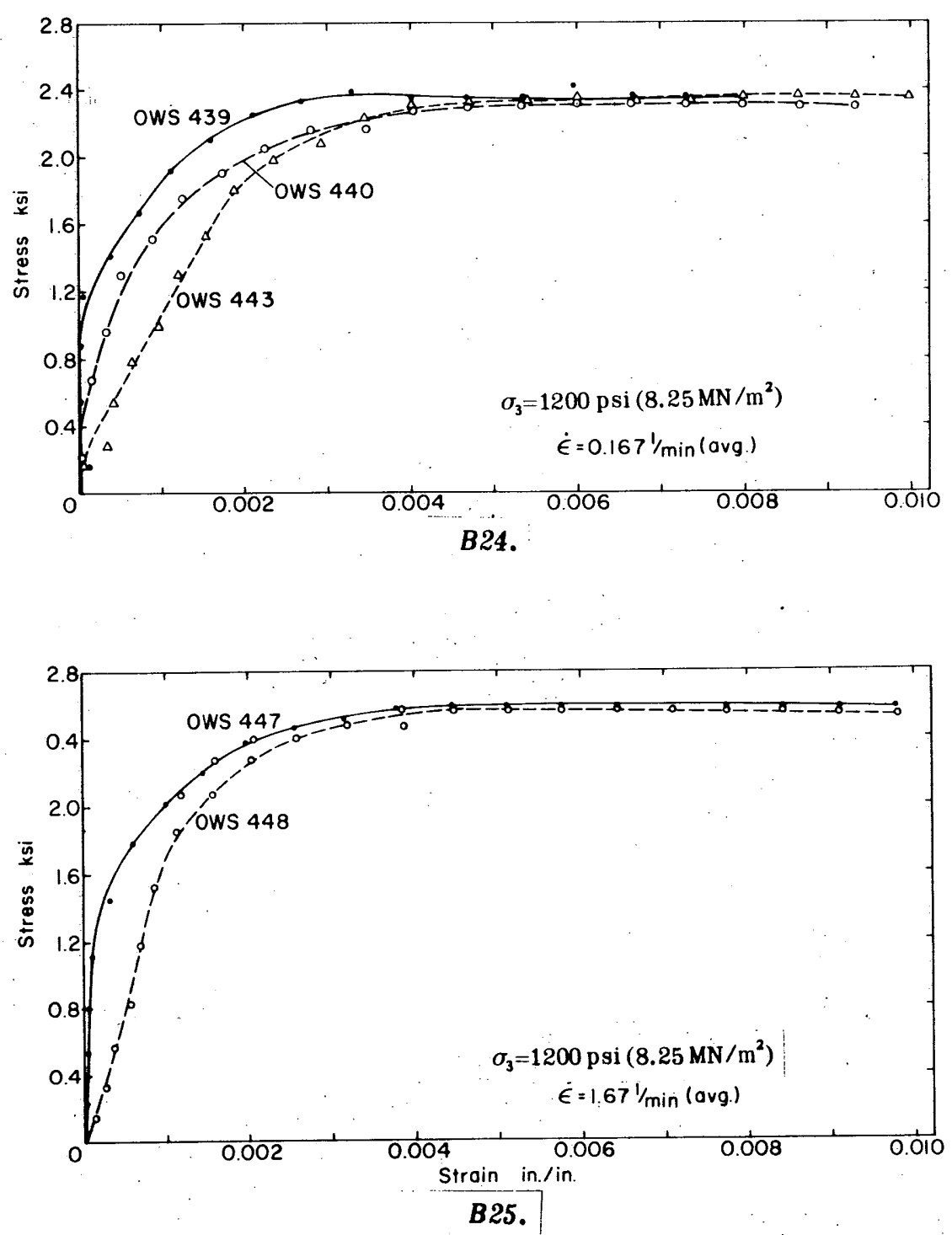
Security classilication of ilfle, body of abtract and indexing annotation must be ontered when the overall report is classified OFIGINA TING ACTIVITY (Corporale author)

U.S. Army Cold Regions Research and Engineering Laboratory Hanover NH 03755

TRIAXIAL CONSTANT STRAIN RATE TESTS AND TRIAXIAL CREEP TESTS ON FROZEN OTTAWA SAND

4. DESCRIPTIVE NOTES (TYPe of report and inclusive dates)

9. AU THOR(S) (First name, middlo inttial, la at name)

Francis H. Sayles

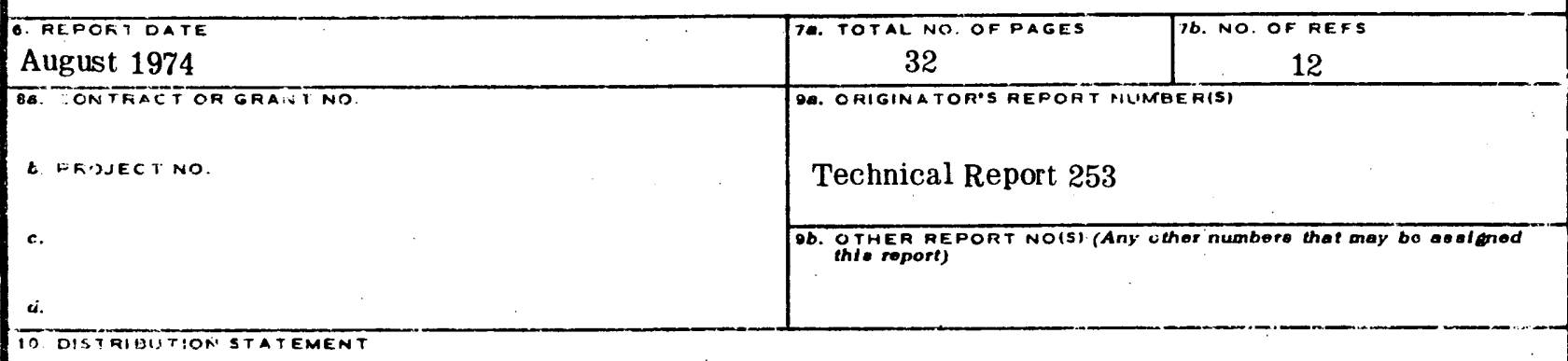

Approved for public release; distribution unlimited.

\begin{tabular}{|l|l}
\hline 11. SUPPLEMENTARY NOTES & $\begin{array}{l}\text { 2. SPONSORING MILITARY ACTIVITY } \\
\text { Directorate of Military Construction } \\
\text { Office, Chief of Engineers } \\
\text { Washington, D.C. }\end{array}$ \\
\hline
\end{tabular}

Saturated frozen Ottawa sand cylinders and polycrystalline columnar ice were tested in the laboratory under triaxial compressive stress conditions using: 1) constant rate of axial strain, and 2) constant load, i.e. creep tests. The constant rate of axial strain tests were performed by applying axial strain rates in the range from 0.1 to $50 \%$ per minute and confining pressures from 0 to $1200 \mathrm{psi}\left(84.4 \mathrm{~kg} / \mathrm{cm}^{2}\right)$. The triaxial compression creep tests were conducted for time periods up to $3000 \mathrm{hr}$ using a range of confining pressures from 0 to $800 \mathrm{psi}\left(56 \mathrm{~kg} / \mathrm{cm}^{2}\right)$ and deviator stresses from 37.5 to $1000 \mathrm{psi}\left(2.6\right.$ to $\left.70.3 \mathrm{~kg} / \mathrm{cm}^{2}\right)$. The resulting stress-strain curves and Mohr envelopes for the constant rate of axial strain tests indicate that at rates of strain greater than about 0.02 per minute, the ice matrix fractures prior to the development of friction between the sand grains. At slower rates of applied strain, the friction between sand grains develops, presumably because ice has sufficient time to creep from between the sand grains. The relationship between the observed maximum deviator stress $\sigma$ and the applied strain rate $\dot{\epsilon}$ can be represented by the empirical expression $\sigma=B \dot{\epsilon}^{a}$ for all the conf ining pressures tested, where $B$ and $a$ are constants. Results from the triaxial creep tests show that creep strength increases with confining pressure and axial creep strain is reduced by increasing the confining pressure. It is suggested that the long-term ultimate creep strength of saturated frozen sand is a function of the internal friction of the sand which could be determined through triaxial tests on freely drained unfrozen sand.

14. KEY WORDS

Creep properties Ice Soil properties

Frozen soils

Permafrost Soil tests 
